\title{
Hattarnas akademi
}

Om de två föregående kapitlen har haft en företrädesvis tematisk struktur och fokuserat på det beständiga i Vetenskapsakademiens tänkande kring samhället, är detta kapitel huvudsakligen kronologiskt orienterat och mer inriktat på dess föränderlighet. Det undersöker akademiens åsikter och visioner om samhällets ekonomiska organisering, alltså den ekonomiska ideologin, och hur de samspelade med hattarnas, mössornas och Gustav III:s regimer. Kapitlet sönderfaller i fyra avsnitt, som behandlar sammanslutningens ekonomiska ideologi i anknytning till hattpartiets första maktinnehav, mössornas styre, hattarnas andra tid vid makten samt det gustavianska väldet.

\section{Hattvänlig hushållning}

Vetenskapsakademiens nära band till hattpartiet framgår redan av de sex grundarna. Hälften av dem - Sten Carl Bielke, Carl Wilhelm Cederhielm och Anders Johan von Höpken - var adliga ämbetsmän och politiker, de övriga - Jonas Alströmer, Carl von Linné och Mårten Triewald - var ofrälse lärda och entreprenörer, varav två adlades (Alströmer, Linné). Alla utom en av stiftarna sympatiserade med hattpartiet. Hovrättsjuristen Bielke hörde till oppositionen, men tilltalades av hattarnas näringspolitik och gynnades av regeringen; hans politiska hemvist reflekterade sannolikt vänners och släktingars ställningstaganden mer än någon personlig övertygelse. ${ }^{342}$ Cederhielm, Höpken, Alströmer och Triewald manövrerade inom de "ekonomiska, politiska och sociala nätverk som var grunden till hattpartiet". ${ }^{343}$ Cederhielm satt som riksdagsman för hattarna, medan Höpken, akademiens främsta tillskyndare och dess 


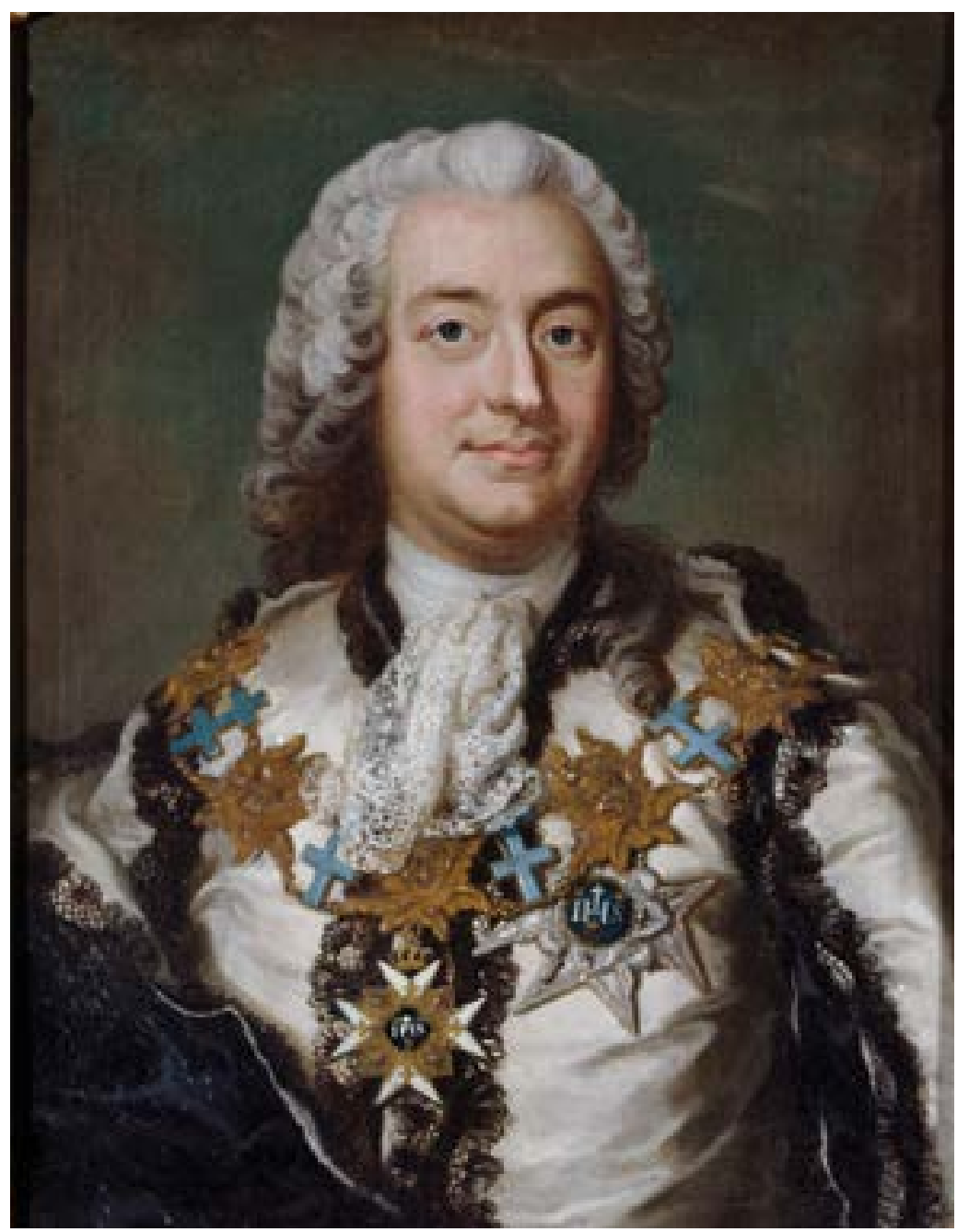

Bild 7. Carl Fredrich Brander, Anders Johan von Höpken, 1712-1789. Foto: Nationalmuseum. Hattledaren och akademigrundaren Höpken.

sekreterare 1739-41, krönte en lång bana i partiets tjänst med att bekläda riksråds- och kanslipresidentämbetena. ${ }^{344}$ Alströmer utnämndes till kommerseråd och bedrev näringsverksamhet som subventionerades av hattregimen. Triewald utgjorde den förmedlande länken mellan hat- 
tarna och Linné. ${ }^{345}$ Meningarna om Linnés politiska sida har förvisso varierat, och det står klart att han inte var särskilt hågad för politik. Hans försänkningar i hattpartiet ger ändå en tydlig fingervisning om var hans sympatier ytterst låg. ${ }^{346}$

Linné kan i detta hänseende jämföras med Pehr Wilhelm Wargentin, en av Vetenskapsakademiens nyckelaktörer och organisationens sekreterare 1749-83, som också hade påtagliga förbindelser med hattarna. Wargentin beskyddades som Uppsalastudent av hattpolitikerna Carl Gyllenborg, Fredrik Gyllenborg och Clas Ekeblad och som akademisekreterare av hatten Carl Hårleman, vars systerdotter han gifte sig med. ${ }^{347}$ Han var vän med både Höpken och Carl Gustaf Tessin; han och några andra ledamöter brukade regelbundet träffas hemma hos Tessin när denne vistades i huvudstaden. ${ }^{348}$

Wargentins band till makthavarna var inte enbart informella. Under hattväldet drogs han och Vetenskapsakademien in i det statligt regisserade arbetet med befolkningsstatistiken, som tillkom delvis på akademiens initiativ. Denna demografiska inventering utgjorde ett led i strävandet att förbättra Sverige genom att öka folkmängden, vilken hölls för att vara rikets främsta resurs. Kartläggningen av befolkningen resulterade i Tabellverket och Tabellkommissionen, där Wargentin spelade en framträdande roll. ${ }^{349}$ Akademisekreterarens politiska umgänge och lojaliteter straffade sig vid mössornas maktövertagande 1765, då han tvingades bort från den kommission som utsetts för byggandet av Trollhätte kanal, för att återinträda i den när hattarna kom tillbaka i regeringsställning 1769 . $^{350}$

Det skulle föra för långt att mera i detalj gå in på Vetenskapsakademiens kontakter med hattpartiet. För att nämna ytterligare några exempel gick flera tunga ledamöter verksamma vid Uppsala universitet - läkaren Nils Rosén von Rosenstein (Rosén; Rosenstein den äldre), matematikern Samuel Klingenstierna och astronomen Anders Celsius - i Carl Gyllenborgs ledband, medan Johan Carl Wilcke gynnades av Höpken och hattriksrådet Ulric Scheffer. ${ }^{351}$

Patrik Winton och Karin Sennefelt har kritiserat den traditionella betoningen av de frihetstida partierna. De polemiserar - med rätta mot en enkel uppdelning i partier och mot ett ensidigt intresse för dem 
på bekostnad av andra aspekter av frihetstidens politik och de vidare sociala faktorer som inramade den. Deras tyngdpunkt ligger i linje med detta på alternativa ingångar till periodens politiska liv, främst sociala nätverk. Winton går ett steg längre när han argumenterar för att partierna närmast var "diskursiva konstruktioner" och förnekar existensen av hierarkiska partiorganisationer med funktionärer, fasta anhängare och långsiktiga agendor. ${ }^{352}$

Det går emellertid inte att komma runt att de båda rivaliserande partierna var fokalpunkter i frihetstidens politiska liv, vilket analysen nedan inskärper. Det är förmodligen mest konstruktivt och rättvisande att betrakta dem som noder i överlappande nätverk, eftersom de var lösa uppsättningar av aktörer med sinsemellan bitvis olikartade föresatser. Det är inom dessa noder möjligt att urskilja relativt varaktiga och välorganiserade kärnor, som ännu mera än de omgivande nätverken hölls ihop av personliga förbindelser, grupplojalitet samt gemensamma tänkesätt, mål och sociala förutsättningar. ${ }^{353}$

Hattarnas långa maktinnehav medförde därtill att deras nätverk blev interfolierade med den institutionella ordningen, varför hattväldet kan betraktas som ett system där såväl nätverken som offentliga inrättningar som Jernkontoret, Riksbanken, Växelkontoret och Stockholms magistrat ingick. Partiet befolkades till stor del av ämbetsmän och hade ett fast grepp om statsförvaltningen, vilken beskrivits som dess "administrativa fasad". Kollegierna fortfor att vara hattrogna efter mössornas maktövertagande och intog en fientlig attityd till rikets nya styresmän, till den grad att ämbetsverken år 1768 bidrog till mössregeringens fall genom en arbetsnedläggning som framtvingade en urtima riksdag. ${ }^{354}$

Hattpartiet och ämbetsmännen var nära lierade med städernas förmögna entreprenörer: "Kommerskollegium drev i stort sett samma politik som skeppsbroadeln; intressena var gemensamma, personerna till någon del identiska. Bergskollegium och även kanslikollegium stod inte långt ifrån. De politiskt dominerande hattarna återfanns i samma läger, ja hörde hemma på kollegierna eller i den handelsidkande storfinansen." ${ }^{355}$ Den ekonomiska politiken var företags- och manufakturvänlig, protektionistisk och regleringsorienterad. Lån, subventioner, skyddstullar, importförbud och exportpremier utgjorde centrala element 
i hattarnas välfärdsprojekt, som syftade till att minska varuinförseln, åstadkomma en bättre handelsbalans samt göra landet mer oberoende, rikt och mäktigt. Utländska konsumtionsvaror skulle ersättas, substitueras, av inhemska och exporten ledas om från obearbetade råvaror till förädlade produkter. För att stärka manufakturväsendet, som uppbar privilegier och inte skulle utsättas för allvarlig konkurrens, befanns ökad arbetsfördelning mellan näringsgrenarna, speciellt städernas och landsbygdens näringar, vara nödvändig. ${ }^{356}$ Inom utrikespolitiken uppvisade hattarna en pro-fransk tendens och en patriotisk-revanschistisk ådra, vilken framför allt yttrade sig i deras olycksaliga ryska (1741-43) och pommerska (1757-62) krig. ${ }^{357}$

Samtidigt var hattpartiet lika litet som Vetenskapsakademien åsiktsmässigt homogent. Det fanns meningsmotsättningar om såväl jordbruket och handelsbalansen som de ekonomiska regleringarna och förbuden, vilka ifrågasattes när de förväntade resultaten uteblev. Till exempel företrädde riksrådet Carl Fredrik Scheffer, som senare kom att anamma den franska fysiokratismen med dess emfas på lantbruk, äganderätt och större näringsfrihet, en mer generös privilegiepolitik för manufakturerna. Under 1750-talet anslöt sig högt uppsatta politiker som Höpken och Tessin till de kritiska rösterna, och den förfelade inrikes- och utrikespolitiken fick till följd att hattarna och deras förenande band alltmer luckrades upp, även om partiet fortsatte hållas samman av "det beståendes makt och tyngden af det gemensamma förflutna". 358

Ekonomiska och ekonomisk-politiska spörsmål intog, som påpekades i inledningen, en framskjuten position inom Vetenskapsakademien. Wargentin definierade organisationen som "en Oeconomisk Vetenskaps Academie". Han liknade hushållningen och vetenskaperna vid barn som växt upp tillsammans, vårdats och handletts av samma ammor och fortfarande var i behov av kärleksfull omvårdnad för att nå mogen ålder, varför akademien inte "trodt sig [...] böra åtskilja så samse [likartade] syskon, utan snarare velat inom sig ännu mer förena dem, då hon tagit sig före, at med lika flit påyrka bägges deras tilväxt”. En snarlik uppfattning återfinns hos Johan Fredrik Kryger, som hävdade att konsterna, slöjderna, handeln, rörelserna och näringarna var vetenskapernas "samsyskon". 359 
Presidietalen lade sig under hattpartiets första period vid makten som regel nära regeringens ekonomiska politik, bland annat genom att de framhöll och förordade slöjder, produktförädling och exportpremier. ${ }^{360}$ Det hette att handslöjder vid sidan av vetenskaper och fria konster var "de största kännemärken af et förnuftigt Creaturs härliga förmoner", liksom att samtidens välfärd utgick från förstånd, handel och slöjder. De som ägnade sig åt konster och slöjder skaffade inte bara sitt eget uppehälle, utan tjänade också andra, eftersom hantverkarna och manufakturisterna försörjde många och mötte vardagslivets behov. Jordbrukets upphjälpande var avhängigt handeln, städerna och städernas näringar, låt vara att stadsväsendet för tillfället var otillräckligt. Handslöjderna borde i enlighet med det synsättet förbättras först, medan lantbruket förhoppningsvis skulle utvecklas i den takt som de övriga näringsfångens livaktighet tillät när dess hinder väl hade eliminerats. ${ }^{361}$

Vetenskapsakademiens uppslutning bakom manufakturerna och hantverket framgår tydligt av Wargentins hyllning av Jonas Alströmer, som han kallade upphovsmannen till Sveriges främsta slöjder. Wargentin frågade retoriskt om någon titel kunde vara mer hedervärd och fastställde att nästan ingen medborgare torde ha gjort mer nytta för samhället än Alströmer, varför denne med rätta var den första svensk att föräras en byst av riksdagen på Stockholms börs. Alströmer själv avstod från att rangordna näringarna. Han underströk att de alla krävde samma konstanta överhetens omvårdnad som manufakturerna för att riket inte skulle hamna i trångmål, och angav att samtliga ekonomins delar hade förmånen att understödjas av det allmänna och kunde göra ett land mäktigt. Alströmer menade dock även att Vetenskapsakademien avgjort debatten om näringarnas företräde till slöjdernas fördel, att slöjderna tack vare Försynen vunnit nationellt bifall och att främmande länders stora rikedom berodde på blomstrande manufakturer och schäferier. Sveriges förbättring avgjordes huvudsakligen av de omistliga handslöjderna, vilka jämte konsterna skulle ge samhället liv och rörelse. Detta skulle ske med bistånd från jordbruket och en handel som för Alströmer kretsade kring exporten av förädlade och umbärliga inhemska produkter och importen av utländska nödvändighetsvaror och råmaterial som fordrades i det svenska manufakturväsendet. ${ }^{362}$ 
Henrik Jakob Wrede lade i likhet med Alströmer tonvikten på såväl slöjderna som handeln med deras förädlade tillverkningar. Han förfäktade att handslöjder och handel var medlen till blomstring och välmåga, samt att den gudomliga hushållningsordningen förverkligades genom att Skaparens vishet ledde den civiliserade människan till varje slags slöjd, färdighet och snillebragd. Ett bättre resursutnyttjande förutsatte handslöjdernas dagliga tillväxt, medan en positiv och välståndsskapande handelsbalans förutsatte ofullkomliga råvarors förädling för export. Samma tematik påträffas hos manufakturkommissarien Erik Salander, som såg slöjderna som alla näringars motor. Han meddelade att de genererade många konster och kunskaper och stimulerade handeln och relaterade rörelser. Jordbruket och landsbygden kunde inte nå framgång utan draghjälp från slöjderna, handeln och städerna. Slöjderna förädlade en lång rad råmaterial och höll kvar rikedomar i landet som kom resten av näringarna till godo. De skulle föra med sig en drastisk exportökning som var svaret på det rådande importöverskottets skadliga effekter. Salander observerade att varuinförseln från utlandet berodde på en inhemsk produktbrist som skulle försvinna när lantbruket harmonierade med, istället för att strida mot, städernas verksamheter. Han förespråkade i linje med det en arbetsfördelning mellan land och stad, varförutan allmänt välstånd var ouppnåeligt. ${ }^{363}$

Några ledamöter såg jordbruket som viktigt men sekundärt i förhållande till slöjderna och manufakturerna. När ämbetsmannen och hattpolitikern Ulric Rudenschöld (Rudeen) diskuterade lantbrukets betydelse menade han att det knappast skulle förbättras förrän handslöjder och handel givit upphov till fler och större städer, som kunde öka böndernas avsättning och bereda dem fler näringsmedel. Därmed skulle landsbygden leva upp och förse städerna med mer livsmedel och resurser för handel och handslöjder; allmän uppodling kunde bara fås till stånd genom en sådan "cirkel-gång". Liknande tankar framfördes av Samuel Schultze, som hävdade att manufakturerna och deras tillväxt var villkoret för jordbrukets tillväxt och att lantbrukets förbättring vore gynnsam för slöjderna, som fungerade väl och besparade riket miljoner. Schultze anmärkte visserligen att jordbruket och slöjderna uppkommit nästan vid samma tidpunkt och tillsammans utgjorde "människans rätta 
näringsmedel", varför ingen konkurrenssituation rådde mellan dem. ${ }^{364}$ Hans fokus låg dock på handslöjderna, inte på lantbruket.

En del ledamöter identifierade någon av de andra näringarna som den mest väsentliga sektorn. Slöjdernas huvudrival om denna status var jordbruket. Vid 1750-talets början betraktade Kammarkollegiums president Carl Fredrik Piper lantbruket som de övriga näringarnas grundval, medan Carl Gustaf Löwenhielm slog fast att det inbegrep allt nödvändigt och utgjorde fundamentet för såväl enskilt välstånd som rikets makt. Liknande föreställningar dök upp igen ungefär ett decennium senare, omkring 1760. Enligt Wargentin var alla näringar likvärdigt värdefulla för Sverige, och jordbruket och handslöjderna lika förtjänta av tillbörlig uppmuntran och vård, fastän kostnaderna fått regeringen att dra sig för att rikta dylika åtgärder till lantbruket. Han kallade å andra sidan jordbruket "Rikets förnämsta pelare" och lanthushållningen "en af de angelägnaste Vetenskaper". Jacob Faggot framställde jordbruket som den främsta näringen, givet att de flesta fann sin utkomst där och att avkastningen var större än inom andra näringar samt kunde mångfaldigas. Lantbruket stärkte "de andra näringarnes lif och rörelse i samma mon, som han [det] får större eller mindre krafter. I följe häraf kan det slutas, at denna vår hufvud-näring, förtjänar den ömaste hjälp och omvårdnad”. Faggot, som erkände att han tidigare satt handslöjderna i första rummet, ville inte återuppliva kontroversen om näringarnas företräde, men riktade icke desto mindre kritik mot det ensidiga premierandet av slöjder och fabriker utifrån att födan borde värderas högre än kläderna. ${ }^{365}$

Dessa åsikter kan kopplas till ett långvarigt och starkt lantbruksintresse inom Vetenskapsakademien, vilket går att placera in i en europeisk och svensk agrar reformrörelse som utvecklades parallellt med fysiokratismen. Fysiokraternas program hade få officiella språkrör i det svenska sammanhanget, där traditionen var en vanligare utgångspunkt för jordbruksengagemanget. Allmänna yttranden om jorden som alla rikedomars källa kombinerades ofta med manufakturvänliga uppfattningar och behövde inte åtföljas av idéer om jordbrukets primat. Lantbruks- och manufakturvurm var överlag inte ömsesidigt uteslutande, om än debatter rörande näringarnas rangordning förekom, inte minst 
i akademien. ${ }^{366}$ Manufakturernas framgång och rikets välfärd ansågs vara avhängiga en stor befolkning som kunde erbjuda billig arbetskraft, något som i sin tur förutsatte en ansenlig tillförsel av billiga livsmedel, bland annat spannmål. ${ }^{367}$

Salanders yrkande på arbetsfördelning var ingen isolerad företeelse bland akademiledamöterna, vilka liksom hattarna ofta intog en negativ hållning till mångsyssleri. Det var, som kapitel tre i denna bok visat, närmast ett axiom att varken samhället eller ekonomin klarade sig utan makthavarnas försorg. Båda skulle ordnas i välbalanserade system där stånd och näringar nogsamt skildes från varandra. Motviljan mot gränsöverskridanden uppenbarade sig för hushållningens del tydligast i återkommande krav på rigorös arbetsfördelning, som gick tillbaka på en vision om jämvikt mellan näringarna - ett ledmotiv i 170o-talets ekonomiska tänkande - och kunde hämta stöd i naturrätten. ${ }^{368}$

Vetenskapsakademiens kanske mest hårdföra förespråkare för arbetsfördelning var Kryger, som med eftertryck vände sig mot den bristfälliga uppdelningen mellan lands- och stadsnäringar, varigenom det enskilda hushållet kom att likna "et särskildt och enstakat [enstaka] samhälle, hvilket sörjer för sig sjelft, det bästa det gitter och förmår: man undviker det mästa man kan, at nyttja hvarandras handräckning, ja anser den för den bäste hushållare, hvilken är sibi sufficiens [självförsörjande] [...] och gör innom sitt lilla samhälle all ting sjelf, hvad til föda, kläder och husgeråd fordras”. Näringsblandningen vållade fler ekonomiska bekymmer än det gick att förteckna; en korrekt arbetsfördelning skulle däremot befrämja rörelser som gynnade rikskroppens välmående. ${ }^{369}$ Kryger efterfrågade också arbetsfördelning och riktig balans mellan städernas företag, samt specialisering mellan städer och provinser. Om näringarna anpassades efter varje landsorts karaktär skulle liv och rörelse infinna sig, till allmän och enskild nytta. Hans aversion mot mångsyssleri sträckte sig till den interna strukturen vid inrättningar, då han argumenterade för en nogsam uppdelning av slöjdverksamheten genom styckarbete. Andra akademimedlemmar förklarade att en hantverkare skulle bedriva en enda syssla så att oordningen och klåperiet upphörde, att de urbana och de rurala näringarnas sammanblandning var till avsevärt förfång för riket samt att arbetare inom klen- och kniv- 
smidet "gör alt, sig sjelf til största last" och att de olika momenten vid produktionen av bössor "efter den naturligaste ordningen" hanterades av olika personer. ${ }^{370}$

Inte heller vetenskapligt mångsyssleri uppskattades i presidietalen. Idén att den lärde skulle behärska samtliga vetenskaper avfärdades med hänvisning till att detta var omöjligt och utmynnade i missanpassat klåperi på tvärs mot skapelseordningen. Det var bäst om varje vetenskapsidkare uppodlade sin del och höll sig "innom sin Sphere". ${ }^{371}$ Samma ledprincip hade alltså bäring på såväl hushållningen som vetenskapen och kan i båda fallen förbindas med det nischtänkande som dominerade ståndssamhället. ${ }^{372}$

Många ledamöter förhöll sig kallsinniga till import. Det gjordes gällande att den medförde ett ratande av naturliga till förmån för mindre naturliga produkter, och att ett klokt folk som ömmade för sin välfärd borde prioritera sämre och dyrare inhemska varor framför bättre och billigare utländska. Handslöjdernas förbättring skulle stämma den ådra som drog mest pengar ur landet. ${ }^{373}$ Carl Gustaf Tessin undrade om det inte var nog att svenskarna till nästan obotlig skada för sin handel "lånt kram af utlänningen”, utan även måste hämta sina ord från utlandet. Jonas Alströmer tillkännagav att han alltsedan han börjat förorda inhemska yllemanufakturer sökt få till stånd råmaterialets inrikes anskaffande, så att svenskarna en gång skulle kunna bära svenska kläder och slippa vända sig till sina grannar för allt. ${ }^{374}$

Vetenskapsakademiens hattvänliga ekonomisk-politiska linje färgade också påtagligt de presidietal som förde fram i ett eller annat hänseende avvikande åsikter om hushållningen. Tal som betonade bergsnäringen eller jordbruket åberopade samtidigt företeelser som manufakturer, handel och förädlade exportvaror. Detta kan exemplifieras med mösspolitikern och officeren, sedermera fältmarskalken, Matthias Alexander von Ungern-Sternberg, som efterlyste understöd till jordbruket och av allt att döma jämställde dess samhällsnytta med slöjdernas. Han noterade att hantverkets och handslöjdernas anstalter varit framgångsrika och att det nu gällde att stimulera deras tillväxt och göra dem mer förenliga med allmän och enskild nytta. Ungern-Sternberg pläderade i samma text mot import och underskott $i$ handeln och för förädling och 
export av inhemska varor. Svenskarna skulle i Adolf Fredriks efterföljd "förakta öfverflöd och främmande kram och endast finna behag i det vi sjelfve tilverka". ${ }^{375}$

Som den hittillsvarande undersökningen av Vetenskapsakademiens ekonomisk-politiska ställningstaganden demonstrerat var positiva utlåtanden om handel ett stående inslag under hattarnas styre. Presidietal förkunnade att den naturliga och sanna handeln orsakas av att länder saknar vissa produkter och att slöjderna inte kom i rörelse utan att stimuleras av andra verksamheter, enkannerligen handeln, vilken kunde ge liv och tillväxt åt alla slags slöjder. ${ }^{376}$ Enligt Wargentin hade forntidens människor knappast förväntat sig att astronomin skulle gynna "Communication och gemenskapen imellan de längst ifrån hvarandra skilde jordens inbyggare: hjälpa dem meddela hvar andra sina rikedomar och upfylla hvarandras nödtorfter; ja, at de[n] skulle gifva millioner människor tilfälle til näring, utkomst och gagnelig rörelse”. I likhet med slöjderna och konsterna gav handeln upphov till såväl välstånd som yppighet, men det utgjorde inget skäl att opponera sig mot dem - de var pålitliga förbättringsverktyg under förutsättning att överheten genom exempel och lagar förekom missbruk. ${ }^{377}$ Wargentins avslutande reflektion illustrerar tydligt en tendens som framträder i flera ledamöters argumentationer, nämligen att handeln skulle vara rätt utformad och lönsam för riket. Vad ett adekvat handelsutbyte ansågs vara framgår av presidietalens syn på import och export.

Även om en del ledamöter förde resonemang om ekonomisk självreglering förblev sådana åsikter marginella inom akademien under hattarnas första maktinnehav. Edvard Fredrik Runeberg påpekade att det var så mycket enklare för politin att upprätthålla den rätta handelsrörelsen då "rörelsens art och natur, vil sjelf befrämja densamma". Wargentin antydde att det skulle vara möjligt att släppa slöjderna "hand-löse" när de övervunnit sina problem och begrundade hur en stor folkmängd skulle göra att alla hushållningsverksamheter gick liksom av sig själva. Han lyfte å andra sidan fram regeringens betydelse och ansvar för befolkningstillväxten. ${ }^{378}$ Kryger förespråkade avreglering i samband med den förment stora svenska utvandringen, som skulle bekämpas genom rimliga friheter och avskaffandet av hindrande tvång. Refor- 
merna var emellertid begränsade och diskuterades vid sidan av beskydd och belöningar ovanifrån. Till exempel borde de svenskar som valde att återvända hem uppmuntras med offentliga medel och "anvisning til näringars idkande utan hinder". ${ }^{379}$

Somliga presidietal uppvisade en långtgående vilja till reglering. Det framställdes önskemål om att allmogen skulle åläggas att bearbeta sin säd väl och att hålla ordning och rent kring sina bostäder, liksom om att höga överheten skulle föreskriva städerna att nogsamt ta vara på sin gödsel och bönderna som sålde hö och halm där att ta med sig gödseln hem. Folket borde vidare ledas till trädplantering, varvid ett visst tvång torde vara av nöden innan den kunde fortgå av sig själv. ${ }^{380}$

En rad presidietal behandlade frihetstidens insatser och landvinningar, bland annat med avseende på fiske, stenkolsbrytning, handslöjder och järnförädling. ${ }^{381}$ Flera av dem tecknade tillsammans och var för sig en bild av frihetstiden som en period av lycksalighet och nytta. Patriotiska invånare kunde glädjas över manufakturernas och de övriga vackert uppodlade näringarnas uppsving - inte minst handeln och acklimatiseringen av utländska växter hade gått kraftigt framåt. Svenskarna hade börjat bli varse sin lycka och på allvar beakta kännedomen om fäderneslandets styrka och svagheter, medan tilltagande näringar och slöjder kommit att ses som fördelaktigare än folkförödande krig. ${ }^{382}$

En av de mest entusiastiska skildringarna kom från Carl Fredrik Scheffer, vars tal tog upp handslöjdernas och lärdomens förbättring, universitetens goda tillstånd och existensen av alla de påkostade inrättningar som behövdes för att bedriva vetenskap. En "ny och qvik lifs anda" hade enligt Scheffer spridit sig i hela rikskroppen; jordbruket och handeln hade förkovrats, manufakturer och förundransvärda segelfarter etablerats och alla gagneliga anläggningar befrämjats. En lika högstämd redogörelse tillhandahöll Faggot, som uppgav att Försynen väglett svenskarna till förbättring och ordnat så att den mulna himlen klarnat någotsånär. Åtgärder som hemmansklyvningen, storskiftet och lantmäteriverksamheten var de mest omfattande som någonsin vidtagits till den förfallna rikshushållningens förbättring. Riksdagen 1755-56 beslutade om så förträffliga författningar att den var att betrakta som "början til folkökning, Lands-cultur [lantbruk] och våra andra näring- 
ars lif". Året 1756 skulle förbli "i en kär åminnelse, och i vår Svenska Oeconomiska Histostoria [sic], en tid utan like". ${ }^{383}$

Faggot var inte ensam om att lyfta fram de styrande hattarnas roll i och för den gynnsamma utvecklingen. Vetenskapsakademiens höga herrar prisades för sin satsning på manufakturväsendet och regeringen för sitt nyttiga förbättringsarbete, som utgjorde grunden för slöjderna och framtiden skulle ha skäl att ära. Textilindustrin åstadkom utmärkta resultat med överhetens bistånd i form av uppmuntrande premier och omvårdnad om de flesta nya anstalter. Sunda författningar hade utfärdats till järnförädlingens fromma och "höga vederbörande" visat ömhet om den genom att till exempel motverka import. ${ }^{384}$

Särskilt Wargentin uppehöll sig vid de frihetstida framstegen. Akademisekreteraren hävdade att samtiden präglades av ett mer utbrett och förfinat hushållsvett. Patriotism hade gjort regeringen driftig och vetenskaperna nått så långt att Göta älv blivit farbar, ett projekt vars svårighetsgrad motiverat ständerna till förnyade och desto mer framgångsrika ansträngningar. Vetenskapsakademiens medlemmar sades glädja sig över att leva i en lycklig era där slöjderna noga hölls efter och liksom resten av näringarna var föremål för mycken uppmuntran och omsorg, vilket förebådade en ljus framtid. Wargentin framhöll den upplysta regeringens mått och steg för slöjdernas igångsättande och utveckling, låt vara att dessa fortfarande drogs med svårigheter och att allmänheten inte hunnit ta dem till sig. Såäl Adolf Fredrik som riksråden fokuserade på att förbättra handeln, och regeringen hade vinnlagt sig om att upphjälpa järnförädlingen. ${ }^{385}$

Wargentins svar till Carl Fredrik Scheffer bjöd på en veritabel lovsång över frihetstidens Sverige:

Uti hvad för et lyckligt tide varf hafve icke vi lefvat och lefve ännu? då under fridens lugn och frihetens skygd så mycket godt, til Fäderneslandets sanskyldiga nytta och heder, blifvit uträttat; så månge härlige inrättningar gjorde och i hast stadgade; så många stora snillen alstrats; så månge befordrare funnits [- - -] Glada tider! då det almännas och alla goda sakers välgång är de myndigaste Mäns käraste fägnad: då, at af dem blifva hedrad och ansedd, ej mer behöfves, än at vara til något godt skickelig; då alt, hvad dugeligt är, värderas och på sitt ställe nyttjas. 
Sådane äro våra tider; Sådana vänte vi, under en Nådig Konungs hägn och genom Deras tilskyndan, som tänka, tala och göra såsom I, Nådige Herre: som mäta den höga värdighet, hvaruti de sitta, allenast efter det goda de förmå bidraga, til at göra et helt Folk stort och lyckligt. ${ }^{386}$

De som gjorde, talade och tänkte som Scheffer bör ha varit hans kollegor i det hattdominerade rådet, vilka utsagorna om många befordrare och de myndigaste män sannolikt också hänförde sig till.

Presidietalens välvilliga omdömen om samtidens svenska samhälle kan utifrån bland annat de upprepade referenserna till manufakturerna i hög grad läsas som smicker av det inflytelserika hattpartiet, även om monarkerna och den tidiga frihetstidens råd också omfattades av dessa utsagor. Vetenskapsakademiens lojaliteter gentemot och närhet till de styrande färgade märkbart talens samtidshistoriska utblickar, som låg $\mathrm{i}$ linje med maktens och akademiens gemensamma ekonomiska ideologi.

Ledamöterna diskuterade även åtskilliga missförhållanden inom skogsskötseln, bergshanteringen, lantbruket, slöjderna, handeln och sjukvården, vilket kan förklaras med att Vetenskapsakademien i mångt och mycket instiftats just för att angripa landets problem. ${ }^{387}$ Vissa presidietal innehöll mer övergripande resonemang kring dem. Faggot beklagade sig över att svenskarna först sent - men bättre sent än aldrig - begripit att på rätt sätt måna om sin välfärd, fastän de länge känt till att deras näringar var särdeles svaga; han uppmärksammade exempelvis att lantbruket missgynnats och var behäftat med fel som inverkade negativt på Sverige som helhet. ${ }^{388}$ Kryger menade att de götiska förfäderna hade lämnat sina ättlingar ett rike som var mer vanvårdat än något annat europeiskt land och ännu stod kvar i "sånings-tiden". Det fanns dock ingen anledning att gräva ned sig i det förgångna:

Vi böre snarare fägna oss åt den tid, i hvilken vi nu lefve. Vi känne våra brister, och äre ei kallsinnige, eller rådlöse, vid omtankan om deras afhjelpande. Rikets Höglofl. Ständer spara hvarken möda, eller kostnad, til landets bättring; en Patriotisk Regering verkställer med nitisk drift Deras mogna författningar, och tröttnar ei vid, at vaka öfver vår välfärd: vetenskaperna uplifva Svenska snillen, och understödja våra späda inrättningar med mogna råd och fördelaktiga handgrep: vårt hopp växer, vid 
så många kännemärken til våra efterkommandes sällare tilstånd, och ökar vår hog, at efter råd och ämne bidraga til et så hälsosamt ändamål. ${ }^{389}$

Krygers optimism var karaktäristisk för akademiens allmänna inställning. Problemen var till för att övervinnas, inte minst av den hattregim som under sammanslutningens första decennier kontrollerade det frihetstida statsmaskineriet.

\section{Mössorna vid makten}

Sverige drabbades under 1760-talet av en ekonomisk kris med såväl inhemsk som internationell botten där hattregimens vidlyftiga bankoch subventionspolitik och pommerska krig utgjorde nyckelfaktorer. Statsskulden rusade, inflationen grasserade och krisen bröt tilltron till manufakturpolitiken genom att åskådliggöra dess tillkortakommanden. ${ }^{390}$

Kritiken av hattpartiets näringspolitik intensifierades, samtidigt som den offentliga debatten radikaliserades när kraftfulla ifrågasättanden av privilegiesystemet och krav på jämlikhet och folkligt politiskt deltagande framfördes. De regleringsskeptiska och näringsfrihetliga stämningar som missnöjet med och besvikelsen över hattarnas förfelade politik gav upphov till spred sig även inom deras egna led, om än merparten av dem fortfor att sluta upp kring det rådande. Mösspartiet, som tillkom som en reaktion på 1738-39 års riksdag, delade fram till 1760-talet väsentligen sina motståndares ekonomiska vision. Det förhöll sig dock mer skeptiskt till tonvikten på manufakturväsende och storskalig affärsverksamhet, vilket kan kopplas till dess ekonomisk-politiska ideal - sparsamhet och en balanserad budget. Istället betonades jord- och bergsbruket. Ifråga om det frihetstida styrelseskicket skilde sig mössorna från hattarna på flera punkter - bland annat genom åsikten att de styrande skulle vara ansvariga inför de styrda, en ståndpunkt som implicerade folkmakt. Utrikespolitiskt hade partiet en pro-engelsk, pro-rysk och mer försiktig profil. Mössorna kom under 1760-talet att stå för privilegiekritik, minskat manufakturskydd, färre handelsregleringar och allmän näringsfrihet, 
medan de brännmärkte hattarnas ekonomiska politik som destruktiv och egennyttig. ${ }^{391}$

Mösspartiets seger på riksdagen 1765-66 föranledde ingen grundläggande förändring av ekonomin, den ekonomiska politiken eller privilegiesystemet. Maktskiftet fick likväl effekter: näringssubventionerna blev knapphändigare, Manufakturkontoret och det exportbegränsande bottniska handelstvånget försvann och näringsrättigheterna utvidgades. Mössorna inriktade sig inte på den ekonomiska ordningen i sig, utan på en jämnare och bredare fördelning av rättigheter och resurser inom de befintliga ramarna. ${ }^{392}$

Vetenskapsakademien förblev i huvudsak trogen hattarna och deras agenda under denna turbulenta period. Ett exempel på akademiens ekonomisk-politiska ståndaktighet var avvisandet av ett bidrag till en pristävling om befolkningsfrågan som gjorde gällande att näringarna borde få sköta sig själva och att folkbristen och emigrationen berodde på privilegier och regleringar. ${ }^{393}$ Rikets ekonomiska svårigheter hade varit föga synliga i presidietalen före mösspartiets maktövertagande, låt vara att några ledamöter berört dem i förbigående. Det hette då att den begränsade inkomst almanacksprivilegiet gav akademien påverkats allvarligt av krisen och att organisationens verksamhet fortgått utan avbrott "oaktadt en lång kedja af både obehaglige och äfventyrlige skiften i det allmänna”. Abraham Bäck skyllde landets näringsmässiga vanmakt på en av farsoter vållad folkbrist. Han agerade förmodligen apologet för hattväldet när han anmärkte att välsinnade medborgares goda förslag som var omöjliga att genomföra på grund av Sveriges tillstånd skulle visa eftervärlden att hans samtida haft de bästa intentioner. ${ }^{394}$ Situationen härrörde alltså ur omständigheter som ingen, inräknat hattarna, kunde råda över.

En långtgående kritik av hattregimen levererades av Pehr Högström i maj 1765. Högström låg åsiktsmässigt nära sin ekonomisk-politiskt radikale prästkollega Anders Chydenius och företrädde liksom denne mösspartiet vid den pågående riksdagen, där oppositionen några månader senare vann övervikt. ${ }^{395}$ Högström inledde sitt presidietal med att räkna upp ett antal faktorer som kunde förhindra en korrekt och välståndsbringande arbetsfördelning i samhället: geografiska avstånd, 
undermålig initiativförmåga, fattigdom, överilade lagar, "konstlande med snillen och näringsfång, samt tryckande af hårda öfvervälden". Fastän Högström formulerade sig i generella termer är det givet tidpunkten för talet befogat att anta att han anspelade på hattarnas Sverige, som alltså tillskrevs ogenomtänkta lagar, otillbörliga statliga ingrepp och förtryck. En syftning på hattstyret kan anas också i Högströms förmenande att det var angeläget att identifiera grunderna för hur näringar och levnadssätt faktiskt brukade vara fördelade. Politik eller lagstiftning som ignorerade verkligheten var kontraproduktiv och ledde till oordning och felgrepp, till skillnad från den som utgick från verkliga förhållanden. ${ }^{396}$

Högström vände sig mot statlig repression, reglering och interventionism. Han uppfattade tvång i tankar och livsföring som oförenliga med Guds vilja, värdesatte konkurrens mellan fria medborgare och hävdade att "fritt anlagda näringar kunna genom blotta täflan bibehålla sig, utan minsta Öfverhetens åtgärd eller Ämbetsmanna-uträkningar och tvång”. Premissen för att uppnå en riktig arbetsfördelning var att människorna fick följa sina naturliga, gudomligt bestämda böjelser. Västerbottens uppdelning mellan stads- och lantnäringar sades ha tillkommit av sig själv, genom folkets snillrikhet och företagsamhet; de hade fördelat sig baserat på tillgångar, insikter och andra faktorer "utan at genom någon onaturlig blanning hindra eller ödelägga hvarandra". Omvänt hade de västerbottniska städernas brist på handelsfrihet medfört att vissa av deras näringar berövats rörelse och stadga, och det hade på flera håll visat sig vara omöjligt att med förbud utrota näringar som "lika som af sig sjelfve fått rota sig [...] när de annorstädes och hvarest man velat inrätta dem, med inga upmuntringar i stånd kunnat sättas”. ${ }^{397}$ Högström avvek även från sina hattsinnade ledamotskollegor genom att inte omfamna en rigid arbetsfördelning mellan stad och landsbygd. Han noterade apropå Västerbotten att bönderna fann det lukrativt att ägna sig åt hantverk, att sådant bisysslande inte var skadligt för jordbruket samt att städerna låg för långt borta för att deras tillverkning skulle vara relevant för landsbygdsbefolkningen. Allt detta hade givit många idén att separeringen av stads- och lantnäringarna inte i alla stycken skulle få lika goda följder som i de sydliga landskapen. ${ }^{398}$

Wargentins svar bestred inte Högströms ekonomisk-politiska försant- 
hållanden men rättade honom ifråga om Västerbottens lantbruk, vilket beskrevs som otillräckligt i talet. Akademisekreteraren framhävde de nordliga trakternas förtjänster och lycka och att Västerbotten i likhet med det övriga Sverige var helt kapabelt att föda sina inbyggare. Wargentin prisade Högströms kunskaper och insats för Vetenskapsakademien, vars trofaste och älskade medlem han uppgavs vara, samtidigt som svaret framställde honom som en "afsides boende" på tillfälligt besök vid organisationen. Wargentin avslutade med en önskan om att Gud skulle välsigna de rådslag riksdagsmannen Högström deltog i och styra dem till Sveriges bästa. ${ }^{399}$ Bemötandet av Högström kan ses som ett försök att distansera Vetenskapsakademien en aning från hans person och synsätt. Kommentaren om riksdagen går att läsa som ett försök att gestalta akademien som höjd över de infekterade partimotsättningarna inför ett maktskifte.

Kort efter mössornas maktövertagande gick Carl Fredrik Mennander till storms mot hattarnas politik. Biskopen räknade upp en rad aktuella problem, som folkbristen, jordbrukets och städernas undermålighet, fabrikernas nedgång, det tilltagandet antalet ståndspersoner samt den ekonomiska krisens verkningar. Förutom att kritisera väpnade konflikter i allmänhet lyfte han fram hattregimens och Karl XII:s krig; om bara riket fått behålla det manskap som gått förlorat genom dem skulle befolkningen och näringarna ha tagit sig radikalt annorlunda ut. Mennander kungjorde att tiderna blev allt svårare, att mycket återstod att göra och att de naturliga orsakerna till folkbristen var mindre viktiga än de moraliska, som kom sig av människornas begär, laster och förvända anstalter. Denna utsaga kan läsas som ett genmäle till Bäck, vilken året innan givit sjukdomar skulden för folkbristen, men även som klander av de störtade hattarna. Den senare tolkningen stöds av Mennanders kritik av deras krigsföretag och av hans tes att befolkningsökning hindrades "när inrättningar, som i sig sjelfve kunna vara nyttige och nödige, och tjena til större säkerhet och utvärtes anseende, framdrifvas skyndsamare och längre, än Statens krafter och förmåga tillåta”. Här avsågs troligen manufakturpolitiken och de förhoppningar som knutits till den. Mennanders skildring av hattväldet var dock inte alltigenom negativ, då han påtalade att samtliga hushållningsgrenar tillvuxit rejält, 
att uppmuntringarna av hemmansklyvning och skifte haft gynnsamma konsekvenser och att rikets tillstånd förbättrats betydligt. ${ }^{400}$

Samme preses framförde en del åsikter som korresponderade mot den fallna hattregimens ekonomiska politik. Han förespråkade export av förädlade produkter och förhöll sig avog till import. Nästan alla nödtorfter och bekvämlighetsvaror kunde anskaffas inom landet, och livsmedelsinförseln riskerade att ge upphov till den värsta uselhet. Statsmakten ("Kronan") tillmättes ansvar för befordrandet av vetenskaper, konster och alla anstalter som bidrog till näringarnas förbättring. Mennander frångick dock det gängse ekonomiska tänkandet när han karakteriserade jordbruket som slöjdernas grundval och den mest omistliga näringen, medan dess belackare utmålades som äregiriga och vällustiga. Detsamma kan sägas om hans synpunkt att var och en helst självmant skulle anpassa sin hushållning efter det allmänna bästa: "Tvångs-medel äro här just icke de nyttigaste, fast nöden kan göra dem oundvikelige."

Mennanders tal hade vidare en socialkritisk dimension. Han slog fast att ståndspersonerna levde på de närandes bekostnad och bekymrades av deras växande antal när den närande befolkningen försvagats. Ett sådant perspektiv var förvisso ingen nyhet i Vetenskapsakademien; till exempel hade Wrede tidigare argumenterat för att adeln genom undervisning skulle ledas från innehav av offentliga ämbeten till jordbruket och bli närande istället för tärande. ${ }^{402}$ Det kan kopplas till en allmän tankefigur som värdesatte de närande och ringare men inte de tärande och förnämare, vilka inte fick bli för talrika och rubba den rätta balansen mellan de två grupperna. Detta förhållningssätt kunde ha radikala implikationer, i form av just tanken att alltför många besuttna levde på gemene mans bekostnad. ${ }^{403}$

Mennander ogillade också att näringsmedlen samlades i få händer genom monopol och privilegier, och han ville att bönder med stora egendomar skulle bereda andra rätt att nyttja dem. Problematiken kring koncentrerat ägande illustrerades med antikens Rom, där det fört med sig befolkningsminskning och reducerad styrka, stora klyftor mellan fattiga och rika samt yppighet, oenighet och avund. ${ }^{404}$ Både Mennanders kritik av de tärande och hans yrkande på näringsspridning hade, väl att 
märka, instrumentella övertoner. Det handlade om nytta och effektivitet snarare än om egalitarism, som utifrån hans syn på samhället och folket knappast var aktuell.

Wargentin berömde i sitt svar Mennander och undvek liksom i repliken till Högström överlag politiska ämnen, något som bör betraktas mot bakgrund av det nyss timade maktskiftet. Sekreteraren nöjde sig med att nämna Mennanders delaktighet i riksdagsarbetet och instämma om behovet av befolkningstillväxt. ${ }^{405}$ Svaret på nästa anförande, som hölls av botanikern Erik Gustaf Lidbeck, var desto mer politiserat. Lidbeck uppmärksammade den samtida inflationen och arbetskraftsbristen och hoppades att Gud skulle ordna en lyckligare framtid. Hans tal uppvisade en importfientlighet kopplad till inhemsk odling av främmande växter, och förklarade dels att regeringen i flera år vinnlagt sig om skogarna, dels att en länge tilltänkt skogsordning nu underkastats ständernas prövning. ${ }^{406}$ Utsagorna om skogen kan tolkas som ett försvar av hattarna, som fick äran av det nya regelverk riksdagen hade att ta ställning till.

Wargentins svar på Lidbecks tal fastställde att hushållningen hade många brister - framför allt folkbrist, spannmålsbrist och skogsbrist - vilkas åtgärdande krävde en långtgående omtänksamhet. Trots att det inte saknades förslag med avseende på skogsbristen hade få av dem anammats och ännu färre verkställts av lagstiftarna, varför krafttag var av nöden. Dessa erinringar kan tolkas som en replik på Lidbecks uttalande om hattarnas omsorg om skogarna och som en kritik av deras politik på såväl detta som andra områden. Wargentin frammanade därtill en bild av en väsentligen självreglerande befolkningsutveckling:

Människan är altid benägen til sitt Slägtes fortplantning: derföre behöfvas ej särdeles många anstalter, intet tvång, ja icke ens upmuntringar eller förmaningar, utan endast frihet at följa Naturens drift, så tilväxer folkhopen snart nog, om han ock tillika ömt vårdas. Sant är väl det, at det lilla ordet Frihet har mycket at innebära, samt at rätta sättet och måttet deruti äro svåre at träffa: men eftertanka och förfarenhet gifva dem dock vid handen, och vi hafve skäl at hoppas, det [att] et Folk, som råder sig sjelft, säkert finner och vidtager dem. ${ }^{407}$ 
Akademiesekreteraren verkar här ha försökt att navigera i den förändrade politiska verkligheten och markera avstånd till hattarnas program, inte minst deras förkärlek för regleringar.

Lidbeck var långt ifrån den ende som gav röst åt ekonomisk-politiska ställningstaganden som utmärkt Vetenskapsakademien under hattväldet, låt vara att de i högre eller lägre grad tenderade blandas med nytt tankegods. Augustin Ehrensvärd menade att en ökad produktion var avhängig handeln, vilken om den vore utbredd skulle motverka emigrationen. Han tänkte sig ett idealsamhälle i form av en folkrik sjömakt som huvudsakligen försörjde sig själv: "De mästa behof finnas där merendels på egen botten. Man behöfver icke söka föda och beqvämlighet hos utlänningen, eller sin säkerhet uti andras beskydd. Idoghet, handaslögder, konster, handel, rikedom, förstånd, ära, säkerhet och et eget genie, få här sitt hemvist.” Även lantbruket hade hemortsrätt i det imaginära riket och var betydelsefullt för dess välmåga. Ehrensvärd beskrev hur sjömakten optimerade sitt jordbruk, förädlade dess produkter och tillämpade välståndsbringande arbetsfördelning. Specialisering kontrasterades mot mångsyssleri, som låste fast rörelserna i barndom och orkeslöshet och förhindrade deras fullkomlighet. ${ }^{408}$

Justitiekanslern och det senare hattriksrådet Eric von Stockenström (Stockenström) diskuterade handelns nödvändighet och handslöjdernas centrala roll, givet att exporten av deras produkter var enda sättet att skaffa fram pengar till livsmedel. Manufakturerna hade liksom fisket och trä- och tjärhanteringen hjälpt till att förstärka riket, och det föreföll som att Sverige borde fokusera på slöjdernas utbredande och förbättring, som landet hade goda förutsättningar för. Samtidigt fann Stockenström att järnhanteringen var den främsta exportnäringen och att både bergsbruket och jordbruket gav städerna vinst och rörelse. Han var tydligtvis angelägen om att försvara det av hattarna omhuldade och delvis av honom själv instiftade Jernkontoret, som sades ha gynnats av både ständerna och konungen. Det uppgavs ha emanerat ur en audiens där Fredrik I inspirerat en ädel strävan hos de närvarande bruksägarna att fullgöra sina skyldigheter och befrämja varandra. Den senaste riksdagen hade beslutat att bevara och reformera kontoret, vars nytta och framtida potential Stockenström framhöll. ${ }^{409}$ 
Stockenström konstaterade att olika näringsgrenar kunde orsaka problem för varandra och att en vis regering visste "at styra alt til det ändamålet, at missbruken af sig sjelfva qväfvas, och at den gränts, inom hvilken hvar och en närings-rörelse, i anseende til dess naturliga uprinnelse, fått sitt säte, ej måtte blifva så tilsluten, at ju icke den [näringsrörelsen], i mån af dess egen utvidgande drift må, enär det sker tillika med andre näringars befordran, få öka sig så långt, som den i sig sjelf kan komma och äga bestånd”. Näringarna hade följaktligen en viss självreglerande förmåga, och uppdelningen mellan dem fick inte bli för strikt. Stockenström avlägsnade sig än mer från Vetenskapsakademiens vedertagna ekonomiska ideologi när han inte fördömde att jordbruket och bergsbruket var sammanblandade, utan gjorde gällande att de trivdes väl tillsammans och stärkte varandra. Lika avvikande var åsikten att jordbrukaren själv skulle ansvara för hushållandet med sin skog och skepsisen mot lagreglering av böndernas skogsbruk, med hänvisning till att den riskerade förstöra en självgående näring i ett läge där nya utkomstmöjligheter inte var tryggade, vilket skulle inverka menligt på befolkningstillväxten. ${ }^{410}$

En regelrätt apologi för hattarnas manufakturpolitik formulerades av kanslirådet Carl Albrecht Rosenadler, som förfäktade att fabrikernas och handslöjdernas nytta var en obestridlig sanning belagd i praktik och teori: "Man hade trodt Handaslögders och Fabriquers ypperliga bidragande til et Rikes flor, vara i detta Seculo [sekel], genom et allmänt tänkesätt uti Europa och de mägtigaste Nationers efterdöme, så tydeligen å daga lagdt, at knapt något inkast däremot skulle vågas. Så många grundeliga Skrifter äro ock därom hos oss, de förledne fyratio åren, utkomne, och de hafva med så utmärkt bifall blifvit uptagne, at alt vidare utförande [redogörande] kunde synas öfverflödigt." Icke desto mindre spreds en tes om jordbrukets företräde som hotade övertygelsen att det var nödvändigt att bistå manufakturerna och slöjderna. ${ }^{411}$

Merparten av Rosenadlers presidietal viktes åt en uppgörelse med den jordbruksvänliga riktningen, vars förespråkare tillmättes smittosamma irrsatser. Främmande länder och statistiska beräkningar togs till intäkt för att manufakturväsendet genererade nytta, välstånd och makt. Rosenadler fastställde att det företrädesvis agrara Polen låg närmare sin 
råhet och det näringsmässigt mer differentierade Tyskland närmare sin förädling. Slöjder och fabriker hade bättre expansionsutsikter och var mer inbringande än lantbruket - de hade redan givit stor vinst. Han betvivlade inte att fabrikerna och slöjderna skulle åtnjuta beskydd och lovade att de snabbt skulle mogna om bara den dittillsvarande politiken upprätthölls. Dock ansåg han att en klok regering samtidigt banade väg för andra verksamheter, eftersom näringarna var organiskt sammanvävda och rikets förbättring kom an på deras samverkan. Ingen av dem fick undertryckas till förmån för en annan; även jordbruket hade ett värde och behövde uppmuntras. ${ }^{412}$

Rosenadler modifierade liksom Stockenström det tidigare ekonomiskpolitiska synsättet genom att uttrycka tilltro till begränsad självreglering. Alla var inte fallna för samma värv och envar borde, förutsatt att den älskade lagen och hembygden, tillåtas följa sin begåvning och håg, varvid de enskilda skulle bli optimalt nyttiga för sig själva och för det allmänna. Då skulle människorna beredvilligt söka sig till näringarna istället för att drivas utomlands av fördärvade utkomstmöjligheter: "Näringar likna en öpnad damm, dit vatnet af egen tryckning inflyter, och arbetare tryta icke där, hvaräst de med fördel sysselsättas." Rosenadler lovordade därutöver mössornas kanslipresident Löwenhielm, som till hans och Vetenskapsakademiens förnöjelse stod i färd att tillträda ordförandeposten. ${ }^{413}$

Smicker av Löwenhielm återfinns också hos Kryger, som bland annat kallade honom en av rikets ypperligaste styresmän. Kryger tycks annars ha riktat förebråelser mot både mössorna och hattarna: "Partier kunna strida med sådan häftighet, hvart för sina afsigter, at det allmänna därvid lider, at Näringarne blandas i spelet, och antingen aldrig upkomma, eller råka i vanhäfd." Utsagan röjer dessutom ett negativt förhållningssätt till partiväsendet, något som kan förbindas med den desillusionerade attityd till det politiska systemet som kännetecknade många hattar inemot frihetstidens slut. ${ }^{414}$

Mössregimen utgjorde sannolikt måltavlan för ett resonemang om despotier, som Kryger attribuerade godtycke, impulsivitet, misströstan, tarvlighet och trälaktig rädsla. Ämbetsmännen betedde sig i detta system som tyranner och invånarna hade knappt frihet att andas utan 
att bötfällas eller åtalas. Undersåtarnas egendomar och liv tillhörde inte dem själva, och nästan ingen värre förbrytelse existerade än att vara förmögen. Kryger underströk i kontrast äganderättens värde och redogjorde för hur den var av godo för olika grupper i samhället. Inte minst för borgaren, som visade sig flitig när han fick vara välbärgad utan att avundsjukan lade beslag på hans rikedomar eller omintetgjorde hans berömvärda vinstlystnad. Makthavarna borde betrakta den rike näringsidkaren som förtjänt av särskild aktning: "de hedra honom, efter han gjort sig därtil värdig, genom sin idoghet och sitt fruktbara snille; de anse honom som en Fader, för et stort antal barn, hvilka taga kläder och föda ur hans händer; de afundas ej på hans förmåner, utan skatta Staten lyckelig, at hafva en sådan nyttig Medborgare; och det är deras glädje, när de finna många, som äro begåfvade med samma Naturens och lyckans egenskaper”. ${ }^{115}$ Allt detta går att läsa som en kritik av de förföljelser mössorna utsatte en rad hattar för efter maktskiftet 1765, i synnerhet köpmännen som skött Växelkontoret, vilka anklagades för att ha skott sig på Sveriges bekostnad. Deras straff sträckte sig från böter till livstids fängelse och väckte förbittring. ${ }^{416}$

Andra kommentarer verkar ha avsett de förutvarande styresmännen och låg delvis nära Mennanders kritik av hattpartiet året innan. Kryger framställde samhället som sjukt och näringslivet som rudimentärt. Han anmärkte att en fri regering trots goda grundlagar kunde hamna snett: "Krigs- och äröfrings-lystnaden kan jämväl där få öfverhand [...] egennyttan kan blanda sig både i Lagars stiftande och skipande [...] upmuntringar, belöningar och enskilda friheter [privilegier], kunna utdelas, ej til det meniga bästa, utan efter mannamon [partiskhet]; den allmänna Crediten kan försvagas, genom felaktiga anstalter, och den enskilda, genom rättvisans senfärdiga, eller ojämna steg.” Verkligt näringsvänliga styresmän månade om krediten, bedömde löftesbrott som högmålsbrott och tog sig an varenda näringsgren, under det att bestickning inte var någon genväg till att få eller behålla en bärkraftig näringsverksamhet. ${ }^{417}$

Kryger förblev likafullt lojal mot den ekonomiska ideologi som dominerat Vetenskapsakademien under hattarnas långa maktinnehav. Han hävdade dels att ett förmånligt näringsklimat förutsatte att den som 
hellre använde utländska än inhemska produkter definierades som en fiende till fäderneslandet. Dels, och möjligtvis i klinch med Högström, att samhället skulle tillfogas obotlig skada om ämbetsmän och ståndspersoner lärde sig att betrakta näringar som växter som grönskade eller vissnade av sig själva. Regeringen skulle se till att näringsutövarnas vinst "må tillika blifva Statens", att "Staten" drog maximal nytta av landet och inbyggarna, att ingen näring blev menlig för riket samt att varje näring erhöll sin rätta, av naturen bestämda hemort. Samtidigt skulle frihetsandan åstadkomma frivilligt patriotiskt agerande, och regelverket som tyglade näringsidkarens laster och gjorde dem allmännyttiga fick inte bli för strängt: "Det är lika vådeligit för Näringar, at, genom författningar, afmäta alla steg för deras idkare, och liksom qväfva vinnings-lystnaden, genom Lagarnes tyngd, som at låta egennyttan rasa onäpst [ohämmad] [- - ] den fattige arbetaren, äfven som den penningerike Borgaren, vil ej drifvas som en machine." Det viktiga var att människors handlingar inte stred mot "Statens bästa". Mindre konventionellt var även att Kryger förstod tävlan mellan invånarna som någonting godartat, och att han föreställde sig yttrandefrihet som ett sätt att skapa kunniga samhällsmedlemmar och trygga konstitutionens fortbestånd. ${ }^{418}$

Akademisekreterarens svar till de hattorienterade ledamöterna var i varierande utsträckning politiserade. Wargentin deklarerade att Ehrensvärds tal var värdigt honom och vittnade om hans gynnsamma personlighetsdrag, men underlät att ta ställning till innehållet. Svaret till Stockenström var mer politiskt och hävdade att förekomsten av flera ömsesidigt förstärkande näringar lämnade utlänningarna minsta möjliga vinst. Wargentin betonade visserligen jordbruket men poängterade att andra näringar, som handslöjderna, handeln och bergsbruket, också behövdes och att de bidrog till att förbättra lantbruket. Ett liknande anslag kan identifieras i hans svar till Kryger, vilket förklarade att Vetenskapsakademien skulle biträda varje näring. ${ }^{419}$

Mest politiserat var svaret på Rosenadlers tal, som slog fast att allmänheten hade anledning att förvänta sig upplysning från akademien när skiljaktiga åsikter förelåg i betydelsefulla ekonomiska spörsmål. Även om kanske inte alla samtida iakttagare förstod akademiens utlåtanden som yttringar av välmening skulle framtiden inse faktum och 
hysa tacksamhet mot organisationen. Wargentin anslöt sig efter denna utvikning helhjärtat till Rosenadlers försvar av manufakturerna, vilka han synbarligen sökte få mössregeringen att fortsätta stödja: "Frågan om Handa-slögders nytta [...] är af stor vigt, och har tyckts redan vara så utredd, at den ej behöfde vidare bevis; men efter en och annan åter börjat draga deras nytta i tvifvelsmål, är väl at I [Rosenadler] med nya skäl bestyrkt sanningen. Vi böre hoppas, at en blidare Sol, efter några års oväder, skal befordra dessa angelägna Näringars tilväxt." ${ }^{\prime 220}$ I likhet med sina ledamotskollegor fortfor sekreteraren att färgas av hattperiodens ideologiska positioner samtidigt som dess ekonomisk-politiska hållning luckrades upp.

Löwenhielm höll 1767 ett presidietal om ungdomens uppfostran som tillmätte riket omfattande brister, varnade för ett förestående barbari och i radikal anda pläderade för folkundervisning. Utbildningsväsendets eländiga tillstånd berodde enligt uppgift i lägre grad på läroanstalterna än på yttre faktorer, framför allt författningarna. Mot bakgrund av detta och att han åberopade de åtgärder som med den äran vidtagits av mössriksdagen 1765-66 kan Löwenhielms utläggning förstås som ett angrepp på det kullkastade hattväldet. Han förde också en socialkritisk argumentation jämförbar med men mer utvecklad och långtgående än Mennanders. Löwenhielms tal diskuterade hur vällust, överflöd och lättja leder till en mängd laster, och hur den mytiske antike härskaren Minos av Kreta genom att eliminera dem lättare än genom egendomsomfördelning skapat en jämlikhet som utgjorde grunden för den rätta friheten. Talet andades beundran inför meritokratiska system som det $\mathrm{i}$ antikens Aten, där människor ärades efter förtjänst. Denna princip borde gälla inte minst vid ämbetsverken, där ingen borde utnämnas till någon tjänst som krävde kunskaper utan att dessa tillstyrktes av universiteten och ämbetsverken. ${ }^{41}$ Löwenhielm tyckte illa vara om att förmögna och förnäma av inbilskhet och fåfänga inte ville att deras barn skulle gå i skola med gemene mans, vilket innebar att de förvekligades och varken blev kunniga eller sedliga. Kanslipresidenten tillskrev barn från det högre samhällsskiktet ett lättjefullt leverne och tomma huvuden, och föreslog att deras undervisning skulle underställas tillsyn med hjälp av biskoparna och Kanslikollegium. ${ }^{422}$ 
Löwenhielms sociala kritik hade emellertid klara gränser. Han betraktade det som naturvidrigt att utgå från att alla rikskroppens lemmar hade samma förmåga, myndighet eller anseende. Den jämlikhet han föreställde sig handlade om att undanröja de destruktiva motsättningarna mellan stånden genom att ge alla möjlighet att sträva högre och efter mer i överensstämmelse med sin läggning, kapacitet och potential. Löwenhielm förkunnade vidare att den ostyriga och obetänksamma ungdomen kunde dra avsevärd nytta av i princip konstant lärarövervakning och att utbildningsväsendet skulle vänja denna vid ordning och underkastelse. Utbildningens övergripande mål var att förbättra sinnelaget, tukta viljan, inpränta gudsfruktan och dygd och förmedla ett begrepp om sann ära, vilken bestod "icke uti höghet, rikedom, börd med flere lyckans håfvor, utan uti et ständigt bemödande, at upfylla alla sina plikter emot Gud, sig sjelf, sin Nästa, sin Öfverhet och Fädernesland”. Den villkorade jämlikheten och underordningens didaktik ackompanjerades av en kallsinnig inställning till folket, som ansågs vara okunnigt och egenmäktigt. Den bakåtblickande menighetens deltagande i den romerska republikens styrelse uppgavs ha medfört en kunskapsfientlighet som talet beskrev i termer av "ouplyst välmening" och "det blinda allarmet". ${ }^{423}$ Löwenhielms socialkritiska ansats gick förvisso längre än Mennanders, men hade liksom den påtagliga instrumentella aspekter, som i mössledarens fall förenades med en auktoritär inställning.

Löwenhielm lade stor vikt vid konkurrens, som i hans ögon var alla stordåds moder och kunskapens och sedernas främsta drivkraft. Avundsjuka var till dels mer nyttig än skadlig eftersom den stimulerade tävlan, bringade sinnen i rörelse och framkallade en livlig handlingskraft. Historien och utlandet fick åskådliggöra konkurrensens nytta. Till exempel hade de skolor Sveriges konungar inrättat varit ämnade att generera vetenskapliga framsteg genom tävlan mellan eleverna, och "inbördes täflan i det goda" utgjorde hela den kinesiska styrelsens liv. ${ }^{424}$

Wargentins svar till Löwenhielm smickrade honom genom att ta upp bland annat hans förträffliga insatser för utbildningsväsendet och hans lysande förtjänster ifråga om riket och Vetenskapsakademien. Sekreteraren anknöt till presidietalets tema när han kungjorde att ungdomen skulle undervisas i dygd, gudsfruktan, patriotism samt respekt för lagar 
och överhet, och att den skulle förvissas om värdet av flit. ${ }^{425}$ Några ekon av Löwenhielms sociala kritik står däremot inte att finna.

Samlaren Bengt Bergius refererade och citerade strax innan hattarnas återkomst till makten Löwenhielms Tal, om landt-skötsel från 1751, under det att han prisade hattarna Höpken och Cederhielm. Bergius förklarade att den pågående riksdagen var en lyckosam och historiskt viktig händelse. Ständerna sammanträdde för att se till landets behov och efter moget övervägande sätta in de mest kraftfulla medel för att rädda det. Därigenom skulle vetenskaperna, konsterna och näringarna beredas en gynnsam framtid, och nå en blomstring som gjorde att Sverige åter avundades snarare än ömkades utomlands. ${ }^{426}$ Hänvisningarna till politiker från båda partierna och den allmänna förhoppningen att ständerna skulle röna framgång tyder på att Bergius sökte hålla sig väl med alla under den ännu oavgjorda kraftmätningen. Ekonomiskpolitiskt var talet ganska tunt; Bergius upphöjde jordbruket, vände sig emot import och förespråkade odling av främmande växter, med förbehåll om att vissa av dem inte gick att acklimatisera. Wargentins svar noterade bara att många inhemska djur och växter hämtats utifrån och att mycket antagligen återstod att göra på detta område. ${ }^{427}$

Presidietalen kom under mössornas regering att mera än förut präglas av social kritik och tankar om självreglering, samtidigt som hattväldets försanthållanden dröjde sig kvar. Som nästa avsnitt skall visa förstärktes den sociala kritiken under hattarnas andra tid vid riksrodret medan självregleringen tonades ned, låt vara att föreställningar om nyttofrämjande konkurrens vann mark. Konkurrens låg tematiskt nära avreglering och därmed nära idéer om ett mer självgående samhälle, varför uppslagen om tävlan kan ses som ett symptom på djupgående förskjutningar i den ekonomiska ideologin. ${ }^{428}$ Som nästa avsnitt ger vid handen var den konkurrens ledamöterna laborerade med dock som regel inte en kraft i egen rätt, utan en funktion av makten.

Den manufaktur- och regleringsvänliga ekonomiska politikens företrädare var skeptiska till konkurrens, vilken liksom en marknad lämnad åt sig själv upplevdes som någonting primitivt och som ett hot mot ordningen, säkerheten och sederna. Om dygden och affekterna antogs vara samhällsutvecklingens och ekonomins förnämsta drivkrafter fanns det 
inte mycket utrymme för att gestalta eller sätta sin lit till hushållningen som ett självständigt, lagbundet, opersonligt och förutsägbart system. ${ }^{429}$ Synen på tävlan och en autonom marknad som någonting primitivt kan knytas till en under 1700-talet gängse dikotomi mellan det naturliga och det människoskapade som i sin tur går att förbinda med naturrätten, vilken var sammanflätad med den ekonomisk-politiska diskussionen och för svenskt vidkommande framför allt uppträdde i Samuel von Pufendorfs tappning. Ur Pufendorfs perspektiv hade statsmakten till uppgift att "förbättra och civilisera med det otuktade samhället som råmaterial. Staten var förnuftets inkarnation och instrument och utan den skulle människan vara en vilde". ${ }^{430}$ I bakgrunden anas den aristotelisk-kristna tanken att naturen skapats som potentialitet och att dess aktualitet enbart kan förverkligas genom målmedvetet mänskligt handlande, vilket därvidlag uppfattats som en väsentlig del av vad det innebär att vara människa. ${ }^{431}$

\section{Hattarnas återkomst}

Flera ledamöter visade efter hattpartiets återtagande av makten prov på en i hög grad välvillig inställning till handel, kanske som en reaktion på manufakturpolitikens misslyckande. Det hette att samhället uppfyllde sina behov främst genom handeln, och att sjöfarten band samman världen och gjorde människorna delaktiga i alla dess härligheter, som vore de en enda samhällsgemenskap. Kritik riktades mot dem som i sin okunnighet och dårskap trodde att det som fordom skulle vara möjligt att undvara varuförädling, omfattande handel och mindre nödvändiga tillverkningar. ${ }^{432}$

Johan Liljencrantz gjorde gällande att handel gav liv och rörelse åt de övriga näringarna och ofta var nödvändig för att förbättra ett rike. Handeln hade en avgörande betydelse för välståndsutvecklingen i Sverige och skulle beford ra de tilltagande slöjderna. Liljencrantz menade att naturen försett länder med olika förmåner för att få till stånd handelsutbyten. Han attackerade mot bakgrund av denna tes, i ett resonemang som kan tolkas som ett ifrågasättande av den inplantering Bengt Bergius och Wargentin nyligen förordat, länders försök att producera allt själva: 
DET VILLRÅDIGA SAMHÄLLET

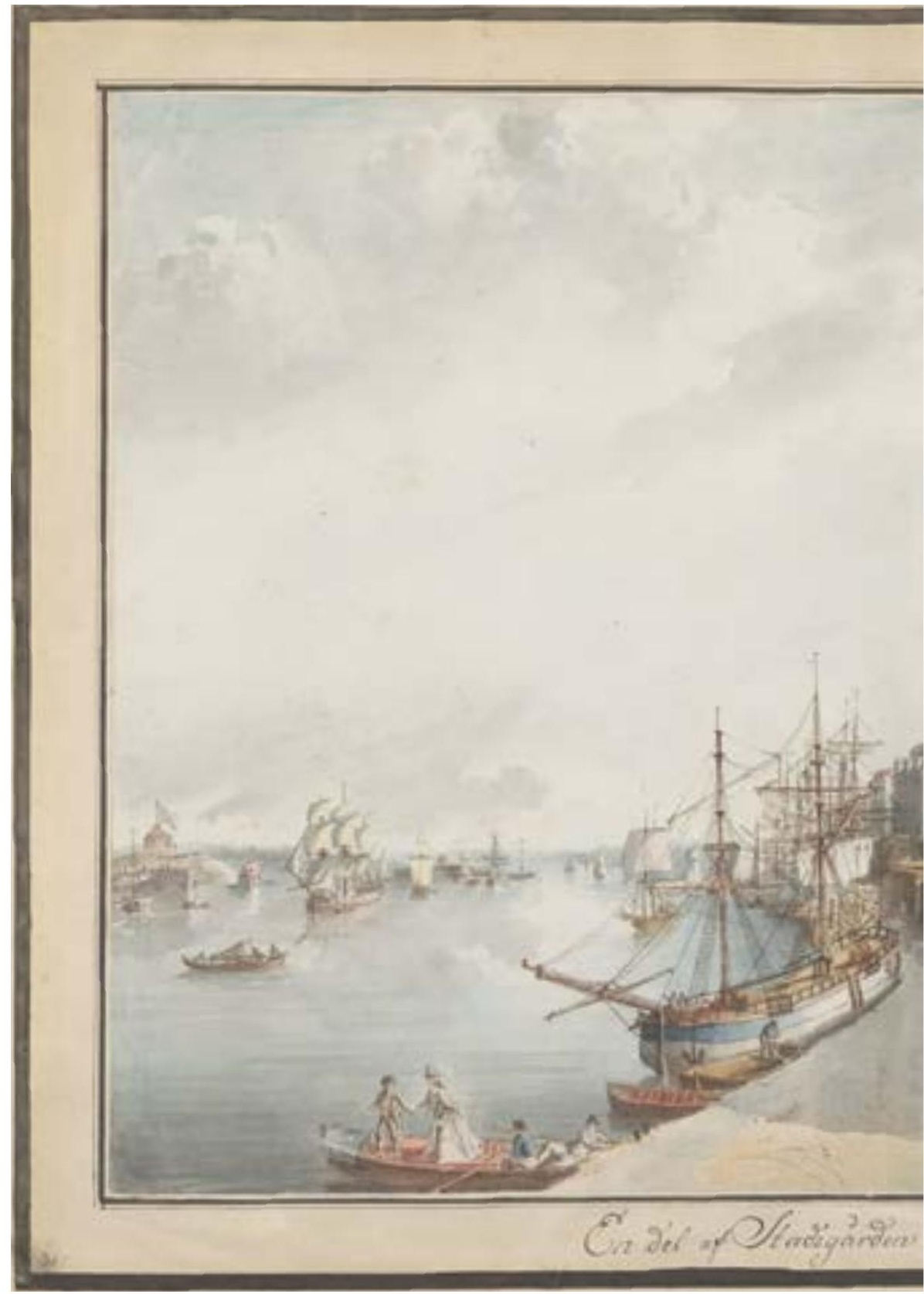

Bild 8. Martin Rudolf Heland, En del af Stadsgården kallad Barlastplaçen. Foto: Uppsala och bejakade export av förädlade produkter. 


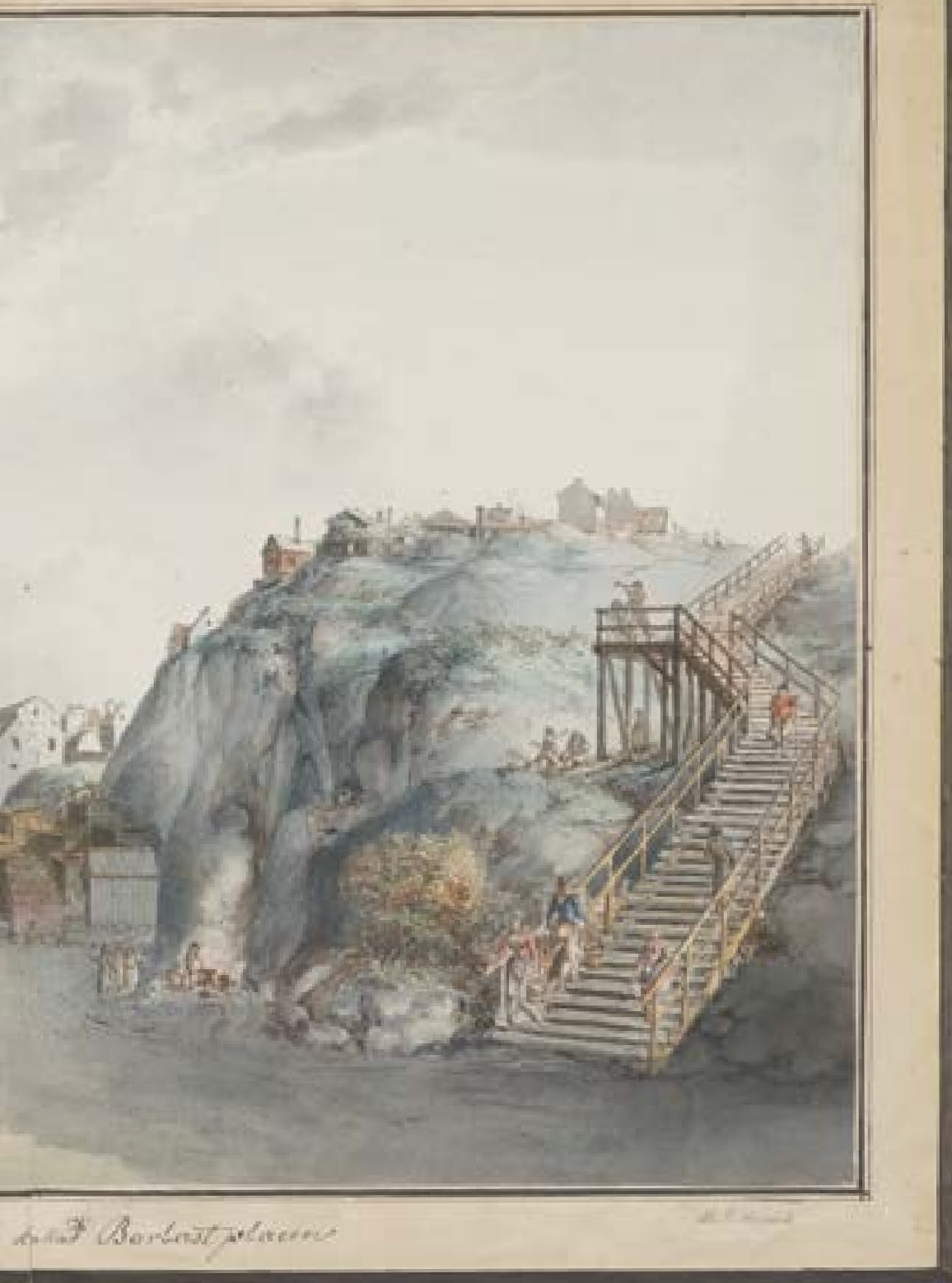

universitetsbibliotek. Vetenskapsakademiens medlemmar ställde sig avvisande till import 
"Det ser ut, som de fleste Riken tro sig ej kunna vara rätt lyckelige, utan at aldeles umbära hvarandra. Inga medel och utvägar, som härtil kunna bidraga, försummas. Och man vil i denna afsigt likasom tvinga sjelfva naturen.” Invånarna i ett kallt land lade trots att de saknade åtskilliga av livets väsentligheter energi på att odla "en växt, som endast är ämnad at förvandlas i rök, och med ringa möda och kostnad frambringas til långt bättre beskaffenhet i de varmare Länder, som naturen ämnat til den sammas rätta hemvist”. Sådant hade sannolikt ofördelaktiga konsekvenser för industrin och handeln, och kunde bara avhjälpas om människorna tröttnade på att gå emot naturen eller om en avancerad internationell konkurrens återställde allting till sin naturliga ordning. ${ }^{433}$

Enligt köpmannen Johan Clason fanns det inget som i sig självt var ett bättre uttryck för strävsamhet än handeln och inget som var så obetydligt att den inte kunde ta det $\mathrm{i}$ anspråk. För att kommersen skulle bli nyttig krävdes emellertid att den fick "sin egen skötsel" och att ett antal samhällsreformer genomfördes. Dit hörde lika rättigheter och skyldigheter, säkerhet för egendom och person samt opartisk och likvärdig rättskipning. Betonandet av jämlikhet åtföljdes av en adelsfientlighet som kan förbindas med det omgivande samhällets infekterade ståndsmotsättningar. Clason lutade sig mot historien och meddelade bland annat att förnämare och förmögnare kringgått överflöds- och yppighetsförordningarna, som dock tillämpats och ännu tillämpades strikt på gemene man. Drottning Kristinas regeringsperiod hade inneburit att de mäktigare inkräktat på de svagare; dess frälse beskylldes för självsvåld och egenintresse, och borgerskapets tillstånd tecknades i mörka färger. En liknande bild gavs av Karl X Gustavs och den efter hans död tillsatta förmyndarregeringens styren, då brist på näringar rådde och borgarna tyngdes av den fåfänga adelns stadsgrundanden. Clason lade skulden på Karl X Gustavs rådgivare, som gynnat sig själva och högfärdigt tryckt ned borgerliga aktörer men omsider tvingats göra eftergifter till det kuvade borgerskapet. ${ }^{434}$

Samme preses ställde sig däremot klart positiv till borgarna. Han framhävde att de svenska konungarna värderat dem som givit statsmakten ("Kronan") inkomst och landet näringar lika högt som dem som varit involverade i rikets styrelse och försvar. Köpmännens hårda 
slit hade gynnat riket och även om dessa inte lyckats förvärva strålande heder borde de åtminstone inte stämplas som farliga, eller som judar och blodiglar. Clason menade att samtidens handelsidkare försvagats och att de skulle vinna större förtroende om deras barn uppmuntrades gå i deras fotspår. Det ökade förtroendet skulle föra med sig stabil kredit och göra att handelsmännen uppfattades som den nationella skatt de verkligen var. Utländska förhållanden användes för att driva hem argumentationen; främmande länder värdesatte sina handelsmän, och engelsmännen och holländarna höll borgerskapet så högt att kungligheter inte tvekade att ingå i dess led. ${ }^{435}$

En likartad apologi för det svenska borgerskapet tillhandahölls av Liljencrantz, som förkunnade att tankar och gärningar, inte ståndstillhörighet, definierade stora män. Få hade bättre möjlighet att gynna samhället och visa människokärlek än köpmännen, varför förtjänta representanter för denna grupp i större utsträckning borde bli ihågkomna. De som omsatte betydliga summor, bedrev vidsträckt handel på avlägsna orter och livnärde tusentals kunde inte "tåla at blifva bortblandad[e] med små-folk”. Sådana köpmän skulle äras så till den grad att de inte längre behövde innehållslösa hederstitlar, och på samma sätt som andra medborgare som var samhällsnyttiga utöver vad deras allmänna plikter föreskrev. De skulle även tillåtas bli rika utan att utsättas för avundsjuka, under förutsättning att rikedomen inte förvärvades på nästans bekostnad. Liljencrantz lyfte fram historiska personer som bruksägaren Louis De Geer, vilka efterlämnat hedrande bevis för sina stora tjänster till riket samt för det förgångnas samvetsgranna belönande av sann förtjänst oavsett social status. Han nämnde också mer sentida, hattanstrukna entreprenörer - "GRILLAR, PLOMGRENAR, med många andra, hvilkas förtjenster af det allmänna äro bekante". Förutom ädel vilja förutsatte de gärningar den sortens aktörer utfört en tillräcklig förmögenhet, som inte kunde samlas om handeln var bristfälligt vårdad och associerad med osäkerhet, eller om köpmännen föraktades istället för att äras. ${ }^{436}$

Clasons och Liljencrantz välvilliga attityd till borgerskapet hade en förelöpare hos Carl Fredrik Adelcrantz. Denne åberopade i sitt presidietal 1757 den naturliga rättvisan, som tillät de ringare att eftersträva 
skicklighet, dygd, belöningar, ära och välmående i lika hög grad som de förnämare. Han underströk att konstnärer och konstkommers inte understöddes bara av monarkerna och de förnäma utan även av borgarna, som naturen berättigade till samma bekvämligheter och förnöjelser som adelsmännen. ${ }^{437}$ I detta sammanhang finns det skäl att erinra om att hattarna var en allians mellan nyadliga och borgare, samt om att de har betecknats som "på sitt sätt radikala", inte minst eftersom de fångade upp borgerskapets utvecklingspositiva strömningar. ${ }^{438}$

Ansatser till en mer subversiv åskådning återfinns i kanslirådet Sten af Rabbes (Rabbe) tal, som uttryckte sig uppskattande om republiker och jämn egendomsfördelning under antiken. Bland annat hyllades den spartanske regenten Lykurgos egalitära samhällsordning som ett mästerverk. Rabbes subversivitet skall dock inte överdrivas, då han inte stod främmande inför makthavare som höll uppsikt över och reglerade samhället. Riken som gick från expansion till begynnande stagnation behövde kloka och uppmärksamma styrande, som visste att i tid motverka dåliga exempel samt var förtrogna med landets resurser och förstod att förmera och fördela dem så att ingen lämnades utan bärgning eller gemenskap med det allmännas väl. ${ }^{439}$

Samtidigt som den sociala kritiken blev mer iögonenfallande vann idéer om nyttofrämjande konkurrens i styrka i den slutande frihetstidens presidietal. ${ }^{440}$ Konkurrensen hade emellertid en annorlunda prägel än hos Löwenhielm genom att den för det mesta förbands med makthavarna och inte framstod som en kraft i egen rätt. En ledamot ville att regeringen skulle uppamma näringarna och få dem att samspela så att riket stärktes i tävlan mellan de upplysta folken. En annan konstaterade att den befordran av näringar och vetenskaper som 1738-39 års hattriksdag beslutat om sammanfallit med en "synnerlig täflan [...] at upfylla ett prisvärdigt ändamål" och att akademiens lycka över Gustav III:s ynnest skulle manifesteras i snillrik tävlan mellan medlemmarna. Liljencrantz beskrev medtävlan som nyttig och uppfattade vid sidan av uppmuntringar inhemsk konkurrens som ett redskap i förbättringen av näringarna. Om svenska kläder fortfarande var för kostsamma borde det noga ses till att produktionskostnaden minskade och att all möjlig medtävlan sattes in. ${ }^{441}$ 
Presidietalen tenderade annars att med modifikationer utlägga det ideologiska arvet från hattpartiets glansdagar. När Liljencrantz fastslog att jordbruket utgjorde ett rikes sanna och säkraste rikedom påtalade han också handelns och slöjdernas värde. De borde värnas och premieras, då de var sammanflätade med lantbruket. Han hyste tilltro till klädindustrin och dess internationella konkurrenskraft, medan manufakturväsendet framställdes som lovande och framgångsrikt. ${ }^{442}$ Liljencrantz anmärkte att varken Levantiska kompaniet eller det understöd företaget uppburit varit behäftade med fel och tyckte illa om den fria handel som följt på bolagets avveckling. Även om handelns behov av frihet var allmänt känt och en fri handel på Levanten kanske kunde vara något för framtiden, hade samtiden behov av ett återupprättat handelskompani med ensamrätt på den tullfrihet som måste till för att förmögna skulle engagera sig. Detta kunde upplevas som inskränkning och tvång men var ändå bättre än en öppen och fri handel som sköttes av ett fåtal personer. Liljencrantz argumenterade i denna kontext mot import av förädlade produkter och för införsel av råämnen i utbyte mot förädlade svenska varor, samt för att export skulle inramas av generella uppmuntringar. ${ }^{443}$

Till Liljencrantz rättfärdigande av slöjderna, rehabilitering av Levantiska kompaniet, fientlighet mot import och tonvikt på export av förädlade produkter kom föreställningar om arbetsfördelning och statlig styrning. Han ansåg att handelsföretagen borde vara specialiserade, och opponerade sig mot den oordning och fördärvliga blandning som han menade var kännetecknande för Sverige. Det bästa vore om köpmännen själva tog itu med specialiseringen i överensstämmelse med den frihet handeln krävde; om så inte skedde borde dock ständerna ingripa och reda upp situationen. Samma interventionistiska inställning hittas i en diskussion om etablerandet av svenska handelskontor utomlands, vilket enligt Liljencrantz primärt var handelsmännens ansvar. Det fanns likafullt en risk att kontoren skulle dröja länge än om inte de styrande fullt ut vinnlade sig om och kraftfullt lade grunden för dem. Handelsmännen antogs dessutom inte bli patriotiska, samhällstillvända och nyttiga utan hjälp av goda författningar och maktens välgörande omvårdnad. 
Författningarna skulle utformas så att köpmännens strävan efter vinning gagnade det gemensammas väl. ${ }^{444}$

Den vedertagna ekonomiska ideologin besjälade också Clas Alströmer, som ogillade import, uppskattade manufakturer och framhöll makthavarnas inflytande över näringsverksamheten. Utländska historiska monarker betraktades som garanter för yllevävandets och fåravelns framsteg; till exempel hade den medeltida kastilianske konungen Alfonso XI:s beskydd av boskapshjordarna besannat ordspråket "Husbondens öga gör Hästen fet". Alströmer tilltalades av Spaniens reglerade fårskötsel och försvarade yllemanufakturerna, grundvalen för flera europeiska länders förbättring och blomstring, och en industri som alltid betytt mer än bergsbruket eller silkesodlingen. Han tvivlade inte på att "dessa slögders anläggande och sorgfälliga vård äfven så mycket å ena sidan stadgat Engelands välmåga, som obekymmersamma försummandet deraf å andra sidan bidragit til vår fattigdom”. Alströmers tal hade därtill mer okonventionella inslag. Han angav att friheten jämte handeln, råvarutillgången och regeringens omtanke låg bakom de brittiska yllemanufakturernas framgång och hyste viss tillförsikt inför ståndspersonernas och allmogens förmåga att på egen hand förbättra fåraveln. ${ }^{445}$

Några av presidietalen smickrade namnkunniga företrädare för hattpartiet. Liljencrantz, som var vänligt stämd till den pågående hattriksdagen 1769-70 och hoppades på dess finanspolitik, komplimenterade en av Höpkens bröder och ett antal hädangångna hattar, inte minst Tessin. Samuel Sandels tog upp Höpkens politiska, vetenskapliga, litterära och personliga fördelar samt positionerade hattfunktionärer som köpmannen Thomas Plomgren jämsides vetenskapsmän som Klingenstierna. Han ställde Plomgrens kollega och meningsfrände Claes Grill i gynnsam dager på grund av dennes insats för Vetenskapsakademiens astronomiska observatorium. ${ }^{446}$

Sandels levererade en regelrätt apologi för Carl Gyllenborgs maktövertagande och styre när han hävdade att ständerna vid 1738-39 års riksdag inte lät någonting

hindra sig, med mindre [än att] Riket måtte sättas i tilstånd, at nyttja sina naturliga förmåner, til vår egen förkofran och sällhet. [- - - Vetenska- 
per, Näringar och rörelser fingo vid den Riksdagen njuta de kraftigaste upmuntringar. En synnerlig täflan förmärktes, at upfylla ett prisvärdigt ändamål. Åtskilliga Snillen framlyste, som öfvat sig i mera, än den Scholastiska Philosophien. Vi njute i detta vårt ljufva Samqväm och sälla lugn en välsignad frukt deraf.

Talet uppställde en katalog över allmännyttiga åtgärder som hade vidtagits under Adolf Fredriks regering, varav många av hattarna, till exempel inrättandet av Åbos ekonomiprofessur och förbättringen av järnindustrin. Trots detta sade sig Sandels utelämna mycket som blivit gjort för vetenskapernas, slöjdernas och hushållningens upphjälpande. ${ }^{447}$

Alla var inte lika intagna av den politik som hattarna fört. Clason slöt upp bakom centrala inslag i deras ekonomisk-politiska program när han förhöll sig negativ till import och drog en lans för exportpremierna och manufakturerna, speciellt Jonas Alströmers Alingsåsverk. Han framförde dock samtidigt kritik mot det ryska kriget, som tillsammans med andra oroligheter varit förödande för Sverige och saboterat läkeprocessen efter stora nordiska kriget, samt mot det pommerska kriget, som förvärrat rikets ekonomiska bekymmer. Clason ställde sig även avvisande till Växelkontoret, som varit "et palliative" och inte ett botemedel. ${ }^{448}$

Frihetstidens sista presidietal, Anders Schönbergs Tal om näringarnas inbördes förbindelse, hölls i mitten av juli 1772, drygt en månad före statsvälvningen. Talet var på många vis ett fullödigt uttryck för hattpartiets åskådning, men hade på samma gång en stark frihetlig ådra. Schönberg tillkännagav här att samtliga näringar var nyttiga och nödvändiga, att slöjderna och lantbruket förutsatte varandra samt att alla näringar skulle gynnas och skapa välstånd med förenade krafter. Trots detta och att talet diskuterade de problem som tryckte jordbruket hade Schönberg ett extra gott öga till slöjderna, som förhindrade att stora ekonomiska belopp flöt ut ur landet. Den som betvivlade dem gick utlänningarnas ärenden och fronderade mot såväl erfarenheten som förnuftet. Fabrikernas nytta för riket bekräftades, och antipatin mot dem beskrevs som en skadlig och vederlagd fördom; upplysta styresmän såg alla slöjder som förmånliga och kände stolthet över fina 
inhemska varor. Å andra sidan framställde Schönberg handeln som hushållningens primus motor, då den gav liv och rörelse åt resten av näringarna, inklusive slöjderna. ${ }^{449}$

Schönberg var en förespråkare för befolkningstillväxt och arbetsfördelning. Han rörde sig med den gängse uppdelningen mellan råvaruanskaffande landsbygd och förädlande och handlande städer, även om han medgav att gränsdragningen inte alltid gick att upprätthålla. Schönberg satte i linje med sin manufakturvänliga inställning städerna och deras näringar främst: "Lantbrukets välstånd, och således äfven de öfrige Näringars i alt hvad däraf beror, härflyter förnämligast af StadsNäringarnas, Handelens och Slögdernes, hvilka följaktigt grundlägga Närings-medlens uphjälpande, och hvarförutan man altid tråkar i gamla spåret, utan at hinna särdeles längre på Närings-vägen." Han hänvisade också i detta sammanhang till erfarenheten, som enligt honom entydigt styrkte att rätt utformade stadsnäringar förbättrade hela näringslivet och gjorde näringarna kapabla att understödja varandra. Städernas undermålighet innebar att landsbygden inte kunde avyttra sina produkter, vilket återverkade på städerna och orsakade inkomstbortfall för bönderna. Resultatet blev att de måste ägna sig åt slöjder, som sköttes illa och kom i vägen för deras egentliga sysslor. ${ }^{450}$

Importfientlighet var ett annat ledmotiv hos Schönberg, som proklamerade att Gustav Vasas tid varit mörk eftersom konungen tvingats införa åtskilliga råämnen, att kortmakare borde räknas som nyttiga medborgare eftersom deras produkt dem förutan hade fått hämtas från utlandet samt att rikets fabriker medfört ansenliga besparingar. En motvilja mot fabrikerna var något för utlänningar som tjänade på frånvaron av inhemska näringar snarare än för svenskar. Schönberg ställde, föga förvånande, export av förädlade produkter i ett positivt ljus; det land var lyckligast som ägde flest åtråvärda varor för bearbetning och handel. ${ }^{451}$

Till det nyskapande stoffet i Schönbergs tal hörde föreställningen att näringarna samspelade bäst utan artificiella element och förordandet av en oinskränkt handelsfrihet som även borde omfatta jordbruket. Behovet av ömsesidigt bistånd mellan näringarna löste sig av sig självt "där vinnings-lystnaden gifver en ny drif-fjäder, at söka all möjelig 
förtjänst”, om bara makthavarna hjälpte till och röjde undan hindren. Den naturliga vinningslystnaden överskuggade samhällsdygdig självuppoffring och fliten behövde ingen annan uppmuntran än att den lönade sig: "idogheten skal då blifva allmän af sig sjelf, den skal belöna sig sjelf, och just igenom denna naturliga belöningen ständigt förökas". Vinningslystnaden skulle trots det hållas i schack och oskälig profit omöjliggöras exempelvis genom att den enskilde tilläts välja sitt eget värv. ${ }^{452}$

Schönberg anslöt sig vidare till synsättet att konkurrens var av godo för näringarna, vilkas framgång dock ytterst berodde på den säkerhet utövarna åtnjöt, som näringsidkare och som medborgare. Talet betonade i hög grad lagar och regleringar. De flesta problem näringarna mötte var avhängiga av eller kunde elimineras med författningar, medan det för deras del betydelsefulla förtroendet mellan medborgarna skulle vidmakthållas genom lagarna. Förutsägbarhet utgjorde av allt att döma en ledprincip för Schönberg, som ville att "alt beständigt" infogades "i en riktig kädja och Systeme, som icke altför ofta ryckes och förändras". Hans fokus på medborgerlig säkerhet kan ha influerats av hur mössorna behandlade hattarna i Växelkontoret. Schönberg menade att förlusten av välbärgade näringsaktörer kunde bli oersättlig, särskilt om skälen bakom var avskräckande, och att de borde tillförsäkras samma trygghet som alla andra "så at inga sken-grunder må vara möjeliga at emot Lag och billighet åtkomma deras förmögenhet, eller hindra dem at använda den til Näringarnas gagn". ${ }^{453}$ Det är svårt att befria sig från intrycket att detta resonemang hade en stark samtidskritisk udd.

En frihetlig hållning utmärkte även Schönbergs kritik av ansatser att dels förhindra eller detaljreglera landsbygdens hantverksproduktion, dels förverkliga sedoläran genom förbud och regleringar. Bestämmelser mot allmogehantverk var lika lönlösa som onaturliga, då det var en följd av städernas otillräcklighet. Om fler och mer tillgängliga städer erbjöd fler och bättre varor till lågt pris skulle uppdelningen mellan landsbygds- och stadsnäringar ske av sig själv. Vad beträffade sedoläran måste upplysta styrande inse att människan önskade "ledas vid sina naturliga böjelser, och icke våldföras til det goda". De lämnade medborgarnas privata övertygelser och uppförande i fred, så länge dessa inte skadade det allmänna bästa. Envar fick inrätta livet efter behag så 
länge han huvudsakligen konsumerade inhemska produkter och inte tog medmänniskors medel i anspråk. Medborgarna skulle dessutom informeras om näringarnas vikt och om sin patriotiska plikt att bidra till det gemensammas väl - i ett näringsidkande land sparades ingen möda på att få invånarna att flitigt ägna sig åt näringsverksamhet. ${ }^{454}$

Slutligen uppvisade Schönberg liksom Clason och Liljencrantz ett socialkritiskt anslag. Schönberg höll före att en låsning vid titlar och rang var menlig för näringarna och att näringssysslor borde ge lika hög status som ämbetssysslor. Han manade till respekt för de mindre välbeställda och ville att de förnäma skulle värdesätta näringsutövning och inspirera gemene man på det området. Schönberg värjde sig samtidigt, som tidigare Löwenhielm, mot idén om ett jämlikt samhälle: "Man förstår lätteligen, at jag icke ämnar förfäkta en dåraktig tanka, den [som] fåkunnighet och afund alstrat, om en oinskränkt likhet i stånd och vilkor uti Samhällen, en inbillad lycksalighet, äfven så omöjelig, som den skulle vara skadelig." ${ }^{455}$

Schönberg var efter Högström och Löwenhielm den som gick längst i ifrågasättandet av Vetenskapsakademiens ekonomiska ideologi. Självreglering och icke-interventionism utgjorde stommar i hans tal, vid sidan av betonandet av författningarnas roll - ett tema som förebådade den gustavianska era på vars tröskel han stod.

Wargentins svar fortsatte att smickra ordförandena och iaktta försiktighet med hänsyn till politiken, som sällan bereddes något utrymme i dem, förmodligen eftersom det politiska läget förblev ostadigt och polariserat. Svaret till köpmannen och hattpolitikern John Jennings nämnde både hans deltagande i riksdagens sekreta utskott och Vetenskapsakademiens tillfredsställelse över ständernas beslut att mer resolut gripa sig an konstruktionen av Trollhätte kanal. Det svar som ställdes till Schönberg lovprisade bland annat hans patriotism och kunskap om de rätta sätten att befordra medborgarnas samfällda lycka. Schönberg karakteriserades som en välsedd riksdagsledamot, som förhoppningsvis skulle få den enda belöning han eftertraktade, nämligen att dygd, tillit, endräkt, näringar, vetenskaper, konster och sann patriotism skulle tillta så att Sverige blev lyckligt. Det är tydligt att Wargentin i stor utsträckning instämde med Schönbergs ekonomisk-politiska ståndpunkter, 
medan omnämnandet av förtroende och enighet försonligt antydde möjligheten av en lösning på parti- och ståndsmotsättningarna. Mest politiskt uttalat var svaret till Clason, där sekreteraren hävdade att ett lands näringar inte fullt ut kunde trivas om de inte uppmuntrades av handeln, vilken borde ge dem liv och rörelse och var att anse som "Själen i Närings kroppen". Riksdagen skulle identifiera och tillämpa kraftfulla metoder för att uppliva näringarna i allmänhet och handeln i synnerhet. ${ }^{456}$

Genom statsvälvningen i augusti 1772 ritades den svenska politiska kartan väsentligen och oåterkalleligt om, något som hade en påtaglig inverkan på både den ekonomiska politiken och Vetenskapsakademiens ekonomiska ideologi.

\section{Gustaviansk ekonomi}

Gustav III:s regering innebar lika litet som mösspartiets styre någon drastisk omläggning av den ekonomiska politiken, vars frihetstida grundsatser låg fast under resten av 1700-talet, om än protektionismen och regleringsviljan mildrades en aning samtidigt som engagemanget för jordbruket ökade och manufakturpolitiken nedprioriterades. ${ }^{457}$ Nyttotänkandet förblev livskraftigt trots en allmän nyorientering i riktning mot vitterhet och sköna konster. ${ }^{458}$ Vetenskapsakademien kom under Gustavs spira att mindre än tidigare uppehålla sig vid ekonomiska principfrågor, som nu oftare hänsköts till makthavarna. Sven Bunges åsikt att de övergripande hushållningsförbättringar som kom an på överhetens författningar befann sig "utom den krets Kongl. Academien sig sjelf föreskrifvit" var symptomatisk för denna utveckling, som går att koppla till ett försvagat intresse för kontroversiella ämnen i den gustavianska offentligheten. ${ }^{459}$

Presidietalen rekommenderade liksom under frihetstiden arbetsfördelning mellan landsorter och näringar, men hade för det mesta en mer nyanserad syn på mångsyssleri. Bunge ansåg att förordningar inte gjorde människor nyttiga och att självreglering borde prägla det ekonomiska förhållandet mellan stad och land. Det allmänna bästa var oförenligt med en noggrann och av förordningar stipulerad gränsdrag- 
ning mellan stads- och landsbygdsnäringar - ömsesidiga behov och naturliga förmåner skulle "af sig sjelfve utsätta en sådan gräns, hvarvid et rådande hushålls-vett säkrast kan vägleda”. Enligt Samuel Gustaf Hermelin hade naturen sett till att provinserna koncentrerade sig på olika näringar, men vissa av dem var i alla fall ämnade till "blandade Närings-medel”. Han menade att allmogens bisysslande i samband med vävandet var nödvändigt och behövde utvidgas, låt vara att det på sina håll redan hade stor omfattning. De landsbygdsspinnerier som betjänade stadsindustrin hörde till de nyttigaste av inrättningar och gav allmogens kvinnor och barn utsikter till inkomst. Endast städerna skulle dock bedriva kommersiell tobaksodling och produktion som krävde dyra anläggningar eller kvalificerat arbete. Runeberg delade in folket i två grupper, stads- och lantborna, som förenades kring de sammanlänkade näringarna och täckte varandras brister. Denna deras gemenskap verkade av naturen forma sig själv och sätta sina egna gränser. Makthavarna fyllde likväl en viktig funktion, givet att "den naturliga relationen, som bör vara imellan dessa folkhopars antal, förändrar sig och kommer ur sit naturliga skick, om mödan och förmånerne å båda sidor icke varda bragte til någon jämnlikhet igenom författningar”. ${ }^{460}$

Andra ledamöter höll fast vid det starka motståndet mot näringsblandning. En av dem var Nils Adam Bielke, som uppgav att Gustav Vasa anslutit sig till den orubbliga sanningen att samhällets fortbestånd förutsatte ordning och därför vinnlagt sig om att skilja landsbygds- och stadsnäringarna åt. Reformationskonungen hade också upprätthållit en arbetsfördelning inom städerna, vilkas hantverkare inte skulle inveckla sig i handel. ${ }^{461}$ Arbetsfördelning fortfor att förknippas med kunskap i Vetenskapsakademien. Det hette till exempel att vetenskaperna inom akademien var "gemensamt vårdade, utan blandning, utan någonderas afsaknad" och att varje bergsman borde besitta såväl specialistkompetens som grepp om helheten. ${ }^{462}$

Även om gustavianska presidietal som regel var negativa till införsel av utländska produkter saknades vanligtvis de hårda omdömen som kännetecknade många frihetstida anföranden. ${ }^{463}$ Bergmästaren Bengt Qvist betraktade utrikeshandeln som ett nollsummespel. Han förespråkade att manufakturerna i första hand skulle nyttja inhemska råvaror 
och att import av mineraler som kunde brytas i Sverige inte skulle ske annat än för att förädla dem och återsälja dem till utlandet. Collegium medicum berömdes för sitt förståndiga beslut att stryka ett flertal poster från apotekens införskrivningslista. Jean George Lillienberg efterfrågade en nationell anda som tog avstånd från smuggling och "okyske begärelser til utlänskt [sic] kram", det största problemet för rikets metalltillverkning. Han målade upp en lycklig framtid där en säker grundval lagts för inrikes näringars upphjälpande och för deras frigörelse från utländska skulder och tvång. För Sandels vidkommande hade den svenska medeltidens största fel inom hushållningen varit att riket låtit utlänningar pracka på sig oumbärliga produkter som det själv kunnat framställa. Utan detta problem hade överflödsimporten inte varit beklagansvärd, lika lite som utrikeshandeln skulle ha medfört någon förlust om den varit måttfull och gått rätt till. Samme ordförande kontrasterade i ett tankeexperiment en evig svensk självförsörjning med vederbörlig hushållning och dito seder mot ett tillstånd där utbyte med omvärlden förändrade idéer och levnadssätt. Han konstaterade att det var olyckligt att ett folk oftast rörde sig mellan ytterligheter och att smaken riktades mot sådant som drog pengar ut ur riket. ${ }^{464}$

De gustavianska presidietalen intresserade sig mer än de frihetstida för acklimatisering av utländska växter, som var på modet under 1700talet och förekom framför allt inom ramarna för manufakturväsendet. Odling av silke och växter som användes för färgning hade haft en särställning under frihetstiden men gick samma oblida öde till mötes som manufakturpolitiken, samtidigt som försök med annan inplantering fortgick. ${ }^{465}$ Anders Sparrman meddelade att Gud placerat gagneliga och omistliga ting i färran världsdelar och att det är en mänsklig skyldighet att leta upp nyttigheter var de än befinner sig, vilket får den gynnsamma effekten att geografiskt vitt åtskilda folkslag kommer närmare varandra. Sparrman underbyggde resonemanget med exempel och påpekade att förståndiga svenska män, fäderneslandets och mänsklighetens välgörare, infört otaliga nya plantor i riket. Han förkunnade optimistiskt att växter går att överföra från ett klimat till ett annat, snarlikt och att mängden nyttiga växter kan utökas överallt. Vetenskapsakademiens roll i acklimatiseringen uppmärksammades av statssekreteraren Matthias 
Benzelstierna (Benzel), som rapporterade att organisationen funnit den under missväxtår tjänliga mangelroten gångbar i Sverige, låt vara att denna gjorde sig mindre väl i ett kallt klimat. Akademisekreteraren Wilckes svar underströk att det var och förblev organisationens föresats att för framtidens skull sätta nyttiga frön i fädernesjorden; därför hade den frekvent och med lyckosamma resultat fört in och demonstrerat förmånligheten av främmande plantor som tidigare varit helt eller delvis okända för svenskarna. ${ }^{466}$

Några akademimedlemmar hade en mer ambivalent hållning till introduktionen av främmande växter. Peter Jonas Bergius gjorde gällande att vissa frukter inte trivdes i det nordliga klimatet medan andra med framgång kunde inplanteras, däribland vinrankor, som han själv odlade. Hans bror Bengt rekommenderade acklimatisering av meloner, fastän Norden inte lämpade sig speciellt väl för dem, men noterade att fikon vantrivdes och att granatäpplen inte lät sig odlas i det kalla klimatet. Ett övervägande kritiskt perspektiv på acklimatiseringsprojekt anlades av Bunge, som slog fast att frihetstidens tilltro till utrikes plantor haft destruktiva konsekvenser: "Man betalar dyrt den ögonfägnaden, at frambringa en främmande växt, när brödet skal köpas. Kriget, näringarne imellan, måste uti så beskaffade omständigheter undfå nytt lif." Han anmärkte att det rått okunskap om klimatets och den geografiska belägenhetens för- och nackdelar, och att vissa trott allt vara möjligt. ${ }^{467}$

Ytterligare en ideologisk kontinuitet med frihetstiden var betonandet av förädlade varor. Wargentin framhöll vikten av inhemsk metallförädling och klandrade de förfäder som sålt stångjärn till utlandet för att sedan köpa tillbaka det i form av dyra bearbetningar. Lillienberg förklarade att bergshanteringen sökte höja mineralers och metallers värde genom förädling och att ingen torde ifrågasätta att de som upparbetade inrikes råmaterial hade företrädesrätt framför dem som drev rörelser baserade på utländska råämnen. England presenterades härvidlag som ett föregångsland, varifrån processer som mångdubblat det svenska järnets pris och gynnat dess export hämtats. Lillienberg redovisade Gustav III:s insatser för metallförädlingen och angav att en förteckning över alla de sentida manufakturer som hjälpt bergshanteringen skulle bli alltför lång. Han varnade för att exporten av grövre metallprodukter riskerade 
att drabbas av problem, varför det fanns desto större anledning att i tid gå in för den lukrativa och hedersamma förädlingen. ${ }^{468}$

Den frihetstida manufakturvänligheten fortlevde i somliga av de gustavianska presidietalen. Hermelin upplyste om att Härnösands linnefabrik hade åstadkommit ansenlig nytta genom att få människor att tillägna sig nya grepp, liksom om att Alingsåsverken varit ett viktigt exempel för den inhemska fabriksutvecklingen och gjort Älvsborgs allmoge begiven på fåravel. Hans manufakturförsvar framgick som tydligast när han insisterade att inte alla resurser som lagts på fabrikerna kastats bort och att riket tjänat mycket på satsningen, som bara skulle bli mer lönsam i takt med att dessa inrättningar tillväxte och förbättrades. En annan apologet för manufakturväsendet var Carl Sparre, som fann att allmän rikedom emanerade ur fria konster, handel och slöjder. Sveriges slöjd-och manufakturvaror var hedrande och lönande för sina upphovsmän, och väckte beundran utomlands. ${ }^{469}$

En del ledamöter riktade tvärtom kritik mot manufakturpolitiken. Ett yttrande hos Lillienberg om "en konstlad och ostadig rörelse-art" syftade av allt att döma på manufaktursystemet, som han även konfronterade mera explicit:

Vi måge icke klandra, hvad andre, i bästa välmening, gjordt; men önskeligt vore, at vi nu hade i behåll något af de stora Penninge-summor, som blifvit utgifne til andra, på utrikes rå-ämnen grundade, och redan til en stor del, kan hända, genom oförsiktig anläggning och drift, förfallne Fabriquer, at i stället kunna användas til Sjö- och Ström-rensningar, Canaler- och Slussbyggnader: Bergsbruket skulle derigenom få et nytt lif, och hushållningen öfver alt i hela landet, et bättre skick.

Bergsassessorn Gustaf Adolf Leijonmarck förefaller ha varit ute i ett liknande ärende då han konstaterade att det nyligen bevisats att oreda och misshushållning inom näringarna och rörelserna riskerade skada utrikeshandeln. Han hävdade också att mindre utvecklade näringar inte borde premieras på bekostnad av mer utvecklade, och att det var fördelaktigt att satsa på flera näringar som kunde förstärka varandra. Sandels både försvarade manufakturpolitiken och lyfte fram att den dragits med korruption, slöseri och missbruk av offentliga medel. ${ }^{470}$ 
Merparten av de gustavianska ledamöter som diskuterade frågan om näringarnas företräde hävdade jordbrukets primat. Lantbruket kallades för den äldsta och nyttigaste näringen, näringarnas moder samt "det säkraste medel, hvarigenom det första och nödvändigaste af alla behof kan upfyllas". Denna huvudnäring utgjorde den främsta grundvalen för rikets styrka och skulle förhoppningsvis snart nå sin högsta utvecklingsgrad, inte minst med tanke på att invånarna och de övriga näringarna led av att inhemsk spannmål var en begränsad handelsvara. ${ }^{471}$ Vetenskapsakademiens agrara ansträngningar berördes tidvis. Det uttrycktes att jordbruket var ett av akademiens stora syftemål och att dess förbättring alltid prioriterats av organisationen, som utlyst angelägna prisfrågor, delat ut uppmuntrande premier och förmedlat nyttig kunskap. Wargentin förklarade att en donation avsedd att befordra lantbruket hade det ädlaste ändamål och att Vetenskapsakademien såg sektorns upphjälpande som en huvuduppgift. Jordbruket var den näring "på hvars förbättring uti vårt kära Fädernesland, vår til de practiske Vetenskapers upodlande egenteligen stiftade Academie, för sin lilla del, troget arbetar, och derföre med största fägnad emottager alla derpå syftande goda råd och föreställningar”. ${ }^{472}$

Samtidigt framfördes liksom under frihetstiden åsikten att en näring inte ensam kunde skapa tillräcklig välmåga. Jordbruket var visserligen en huvudsektor, jämte bergshanteringen, och de verksamheter som förädlade inrikes råvaror stod över dem som utgick från utländska. Ändå måste samtliga nyttiga näringar förkovras för att Sverige skulle höja sig, och idealet var en situation där de samsades och samverkade med varandra. Den som visste sitt eget bästa önskade välgång åt dem alla. ${ }^{473}$

Ett antal presidietal reproducerade den senfrihetstida välviljan gentemot handeln, som påkallades av människors ömsesidiga behov och bevarade och utvidgade de andra näringarna, inte minst fabrikerna. Köpenskapen gestaltades som den politiska kroppens motsvarighet till människokroppens blod, som förde livsandarna till lemmarna; dess jämna lopp var det bästa måttet på välfärd och dess stagnation tämligen riskabel för hälsan och livet, varför denna förtjänade den största omsorg. Såväl Ostindiehandelns nytta och oumbärlighet som fördelarna med Ostindiska kompaniet behandlades. ${ }^{474}$ Rikets handelsmän beskrevs som 
aktningsvärda, snillrika och driftiga, och det allmännas väl som sammanvävt med de penningstarka handelsfirmornas. ${ }^{475}$ Handeln skulle liksom under frihetstiden vara inrättad på ett visst vis. Nils Adam Bielke förfäktade att den för att inte bli menlig måste präglas av eftertanke, kunskap, kärlek till det allmänna och varsam frimodighet. Under Gustav Vasas regering hade borgerskapet till skillnad från konungen haft föga insikt om hur en riktig handel bör bedrivas; denne lät därför införa god ordning bland köpmännen, "på det handelen rätteligen måtte tilgå och styras". ${ }^{476}$ Det yrkades i linje med akademiens importfientlighet på en balanserad handel eller ett handelsöverskott. Köpmannen Carl Christopher Arfvedson inskärpte betydelsen av förädling, export och gynnsam handelsbalans men uppfattade samtidigt ökad varuinförsel som en funktion av allmän välfärd och införseln i sig som godartad, eftersom den underlättade de inhemska tillverkningarnas avsättning och vidmakthöll fliten. ${ }^{477}$

Under gustaviansk tid vann idéer om en mer eller mindre spontan ordning och kritik mot tvång på nytt i styrka. Runeberg fann att utrikes- och inrikeshandeln har "en viss och beständig relation til hvarandra, om författningarna lemna dem båda två et fritt och naturligt lopp". Arfvedson skildrade hur pengar naturligt letar sig fram till den marknad där handeln ger dem deras högsta värde; de och ädla metaller söker liksom vattnet ständigt sin jämvikt och måste flyta dit flitiga människor producerar flest varor till lägst pris. Proberaren Peter Jacob Hjelm avfärdade belöningar för nyodlingar som obsoleta och ogillade att förordningarna mångfaldigades, eftersom det kunde medföra att de glömdes bort och hemmansklyvningen varit framgångsrik utan ett sådant överflöd. Han gav flera exempel på tvång som hämmade den mänskliga trevnaden, vilken "ofelbart beredes och vinnes med mindre konst [artificialitet], men med mera frihet och säkerhet: med mindre Formaliteter, men mera rättvisa". Säkerheten handlade bland annat om orubbliga arrenden och om att bönder och torpare "fritt och liksom af sig sjelfva" kunde starta nya hushåll på lika villkor. ${ }^{478}$

Mest radikal var Nils von Rosenstein, som menade att oreda, lagförakt och lagbrott uppstod om ett orimligt tvång lades på den mest utbredda passionen, begäret efter materiella fördelar. Onaturliga och ogenomtänkta 
bojor på köpenskapen inbjöd till bedrägerier, medan frihet genererade hederlighet: "Öpna alla vägar för idogheten och industrien, och var viss, at dana et arbetsamt och sedigt folk, där bofvar och skälmar äro mera sällsynte. Gör näringarne och handelen så frie, som möjligt är, och antalet af Lagbrytare och Lurendrägare [smugglare] skall aftaga.” Monopols exkluderande tvång utgjorde det bästa argumentet för nyttan av fri handel, som också kunde hämta stöd i historien. ${ }^{479}$

En del presidietal modererade förkärleken för avreglering. Enligt ämbetsmannen Eric Schröder fick tvång och inskränkningar handelsrörelserna att vantrivas och förfalla. Han fastställde apropå spannmålshandeln att Sveriges klimat och geografi gjorde alla begränsningar än mer skadliga, samt att ett allmänt och nyttigt inre handelsutbyte främst kom an på konkurrens och fullständig avsättningsfrihet. Förbud mot och höga tullar på utförsel av spannmål hade haft negativa följder för det svenska jordbruket, och främmande länder som England åskådliggjorde nyttan av fri spannmålsexport. Samtidigt ville Schröder att de styrande skulle uppmuntra handelns aktörer, reglera priset på spannmål som fördes utomlands och avvärja skadlig export och import. Wilcke poängterade i sitt svar till Schröder att en nyttobringande inrikes och utländsk spannmålshandel inte endast skulle vara fri utan även förståndigt styrd. Talets historiskt belagda förslag säkerställde rikets vinst på en vara som under rådande omständigheter gjorde svenskarna till utlänningarnas skattdragare. ${ }^{480}$

Sandels gjorde gällande att författningar ämnade att motverka export och dirigera eller tvinga inhemsk handel medverkat till sädesbristen genom att dämpa åkerbruket och göra intrång på de friheter som var grundade i näringarnas och handelns natur. Gustav III hade i ett lyckligt ögonblick lossat banden och återställt spannmålshandelns nyttiga friheter. Samme preses ställde sig kallsinnig till höga tullar, som drev upp priserna, föranledde smuggling och lade hämsko på näringar och rörelser. Han framhöll relevansen av att vissa hantverkare i 160o-talets Stockholm inte haft någon skråordning och uppskattade att kopparhandeln under detta sekel frigjorts från de delvis monopolistiska kompanier som ombesörjt den. Den gustavianska kopparförädlingen meddelades vara så framgångsrik att utförseln av ren koppar upphörde av sig själv, i 
kontrast till det föregående århundradets export av råkoppar som knappt kunnat stävjas av förordningar. Å andra sidan kopplades en försiktig hushållning till begränsningar och förbud avseende diverse exportvaror, och Karl XI sades ha sett till den långsiktiga nytta som kunde uppnås genom "utdelning af friheter, understöd och belöningar". ${ }^{481}$ Termen "frihet" bör här fattas som "privilegium", givet att den förekom vid sidan av subventioner. ${ }^{482}$ I frihetstida ekonomiska sammanhang hänförde sig "frihet" ofta till rätten att få utöva sina privilegier, inte till en allmän näringsfrihet. "Fri” handel avsåg många gånger den enskildes rätt att fullgöra sin påbjudna samhällsroll utan att störas av andra och ett reglerat varuutbyte inom ståndssamhällets skrankor. ${ }^{483}$ Denna terminologi levde uppenbarligen kvar under det gustavianska tidevarvet.

Konkurrens fortsatte att uppfattas som ett gynnsamt fenomen. Ledamöter anförde att inbördes tävlan gav lägre priser och motverkade smuggling, och att ståndspersonerna förmodligen skulle bli alltmer hågade för "ädel inbördes täflan" och beflita sig om såväl sin egen som rikets förbättring. ${ }^{484}$ Lillienberg betraktade tävlan och förtjänst som de huvudsakliga drivkrafterna bakom en bättre och mer arbetsintensiv bergshantering. När gruvbrytningen ställts om till betingsarbete hade de arbetsamma kommit att tjäna mera än de lata, "och i den mon förtjensten väckt en otvungen täflan, hafva färre arbetande händer kunnat åstadkomma, hvad som tilförene sysselsatt flera”. Lillienberg var dock också i hög grad regleringsorienterad. Han uppgav att både industrin och vetenskaperna krävde livgivande omsorg, medan konkurrensen liksom hos flera av frihetstidens ledamöter förbands med makthavarna. ${ }^{485}$ Konkurrens hade positiva förtecken även ifråga om lärdomen. Det hette bland annat att rivalitet inom lärda samhällen var stimulerande och underblåstes av pristävlingar som satte igång snillen och frambringade förträffliga studier. ${ }^{486}$ Vetenskapsakademien hade givit upphov till en tävlan om organisationens uppmärksamhet och de kloka stiftarna vetat att utnyttja människans naturliga längtan efter erkännande. Ledamöterna tävlade inte bara med varandra, utan med själva naturen. ${ }^{487}$

I några tal framträdde egennyttan som en drivkraft. Bunge menade att den primära orsaken till att stora monarkers och upplysta styres- 
mäns avsikter inte förverkligats i Sverige var gemene mans brist på övertygelse om sin personliga nytta av dem, vilket hade betydelse när hushållningsanstalter skulle verkställas. Schröder förklarade att det var lika överensstämmande med handelns natur att tonvikten lades vid varor med en välgrundad vinstkalkyl som det var överensstämmande med erfarenheten att människor drogs till handelsgrenar med tillfredsställande förtjänst. Vinningslystnad, konkurrens och den enskildes förmåga ställdes i ett gynnsamt ljus. ${ }^{488}$

Ytterligare ett frihetstida anslag som gick igen i de gustavianska presidietalen var den sociala kritiken. Joachim Wilhelm Lilliestråle anmärkte att aktandet på börd utgjorde en för riket oförmånlig vanära och ett oberättigat tvång vid försäljning av fast egendom, som borde ske fritt eftersom säljarens äganderätt var fullkomlig och ren. Det angick inte det allmänna vem som ägde en egendom så länge den sköttes korrekt. Sandels deklarerade att formella distinktioner mellan medborgare som inte utgick från meriter och duglighet resulterade i arrogans, fåfänga och avundsjuka. De kvävde fliten, skapade fler tärande och fick näringsidkarnas förmögenheter och barn att lämna deras företag. Bunge tecknade ett föga smickrande porträtt av adelsmän och rika ofrälse, som enligt honom ofta sökte sig bort från sina lantbruk på grund av äregirighet, fruktlösa nöjen och lyx. Om de besuttna konsumerade all sin avkastning och inget fanns kvar för att förbättra deras egendomar blev det desto mer angeläget att ta tillvara på kapaciteten hos den närande befolkningen, vars kapital bestod i dess arbete och måttfulla leverne. Bunge underströk dock att de närande förväntade sig undervisning och rimlig belöning för sin möda från de mer upplysta. ${ }^{489}$

Jacob Gadolin byggde in social kritik i en redovisning av den enskilda människans upptäckt av världen:

Då hon erfar, at alla menniskor födas til verlden på enahanda sätt, lika nakna och oförmögna, men det likväl händer, at den ena med våld eller list förhindrar den andra at i ostörd frihet jämte sig nytja den välgörande naturens förmoner til nödig bärgning och beqvämlighet, upkommer däraf hos henne den första känning och tanka om rätt och orätt. Skilnaden imellan onda och goda gerningar faller henne så mycket lättare i 
ögonen, som hon ofta icke utan ömaste invärtes rörelse kan åskåda, huru en starkare misbrukar sin styrka at oförrätta den svagare.

Utsagor om att alla föds jämlika och att de starkare förtrycker de svagare kan läsas som kommentarer till den ståndssamhälleliga ordningen. Detsamma gäller fortifikationsdirektören Axel Magnus von Arbins (Arbin) uppskattande iakttagelse att Karl XI förstått att betjäna sig inte bara av ädlingar, utan även av "dem af medelståndet" som genom sin begåvning varit till nytta för det allmänna. Tack vare denne konungs mästerliga förmåga att välja goda tjänare hade ingen tidsperiod "på kortare tid framalstrat flera stora Män, som blifvit stamfäder för nyare slägter, hvilka medelst stora bedrifter vunnit samma rättighet til allmän högaktning hos Samtid och Efterverld, som ättlingar af forntidens Herrsar [hövdingar] och Jarlar". ${ }^{490}$

Rosenstein den yngre, vars tal tillkom under franska revolutionen, stod för den mest uttalade sociala kritiken. Han beskrev hur de förnäma framförde överdrivna anspråk och ringaktade högmodet hos köpmännen, som i sin tur hyste förakt mot en adlig stolthet som ofta kom till korta i praktiken. Det stora folkflertalet urskilde enligt honom samma grundläggande vanvett hos bägge. Adelsmän som hävdade bördens företräde var fördomsfulla och lika oupplysta som vinningslystna köpmän. I båda fallen hade passionen - högmodet respektive egennyttan - en mer dominerande ställning än hos deras upplysta ståndsbröder. Rosenstein talade om "de högas frestelser, deras förfinade, men ock ytliga odling, deras glänsande dygder och sminkade fel" och ansåg att såväl adelsmännen som deras medtävlare köpmännen överlag var giriga och överdådiga. Allmänheten hade likväl en benägenhet att närma sig dem. Mot bakgrund av de högres och de lägres tillkortakommanden blev slutsatsen att "medel-classen" var den mest dygdiga samhällsgruppen. Denna likställdes med nationen och tillskrevs en upplysning förvärvad utanför "den bana, där begären [ut]öfva sit starkaste välde; utan at känna olägenheterne hvarken af de främsta eller lägsta rumen i Samhället". ${ }^{491}$

Trots dessa synpunkter föll Rosenstein som så många andra nytänkande akademimedlemmar tillbaka på invanda idéer. Resonemanget ovan kan kontrasteras mot hans teser att mänsklig behovstillväxt 
leder till ökad ojämlikhet och att en fullständig jämlikhet varken är förankrad i naturen eller nödvändig för lycksaligheten. Egenskapernas ojämna fördelning visar att olikhet ofrånkomligen följer av människans själva väsen. Till det kom att lycksalighet inte handlar om "bättre eller sämre vilkor; uselheten undantagen. Om vi räkna de rikas och de fattigas, de högas och de lågas förnöjda stunder, är ovisst, hvarest öfvervigten blifver". Rosenstein avvisade, med sannolik hänvisning till franska revolutionen, samtidens jämlikhetsyra och dem som inte kände jämlikhetens gränser, kanske till den grad att de inte skulle hejda sig förrän de förstört samhällsgemenskapen. Han framstod som en apologet för de besuttna när han urskuldade att vissa åtnjöt större fördelar så länge dessa flöt ur strävanden öppna för alla, inte innebar förtryck och inte vanns på nästans bekostnad. ${ }^{492}$

Vetenskapsakademiens kopplingar till hattarna reflekterades i att organisationen under partiets första, långa tid vid makten oftast positionerade sig nära regeringens ekonomiska politik, genom att presidietalen framhävde och förespråkade slöjder, produktförädling, arbetsfördelning, reducerad import och bättre handelsbalans. Slöjderna och handeln, som under 1700-talet kunde ställas i motsats till det ursprungliga och råa jordbruket, rankades högst av näringarna. Handeln skulle vara utformad på rätt sätt och lukrativ för Sverige; import sågs med oblida ögon och skulle begränsas eftersom den drog pengar ur riket och gynnade främmande länder, medan export av förädlade varor förordades. Konsensus rådde om nödvändigheten av en strikt och välståndsskapande arbetsfördelning, särskilt mellan stad och landsbygd. ${ }^{493}$ Den hattvänliga ekonomiska ideologin kan också spåras hos ledamöter som framförde i ett eller annat hänseende avvikande åsikter om hushållningen. Några diskuterade ekonomisk självreglering, men sådana idéer förblev marginella under hattarnas första maktinnehav. Presidietalen uppmärksammade vidare frihetstidens nyttiga landvinningar och de styrandes betydelse för den gynnsamma utvecklingen. De välvilliga omdömena kan, bland annat med tanke på de upprepade referenserna till slöjderna, 
i hög grad tolkas som smicker av hattpartiet, även om monarkerna och de förutvarande makthavarna delvis omfattades av dem.

Akademien fortsatte huvudsakligen att solidarisera sig med hattarna under det turbulenta 1760-talet, samtidigt som hårda angrepp kring och efter maktskiftet 1765 riktades mot partiets politik, framför allt från mössorna Högström och Löwenhielm. Både Högström och Löwenhielm fäste vikt vid konkurrens, vilken ur Löwenhielms perspektiv utgjorde en kraft i egen rätt. Konkurrens låg tematiskt nära avreglering och uppfattningar om ett mer självgående samhälle, varför förordandet av tävlan kan förstås som ett symptom på en bredare och djupare omvandling i den ekonomiska ideologin. Löwenhielm gav därtill röst åt en kritik av adeln som var mer långtgående än dess fåtaliga förelöpare i tidigare presidietal. Den sociala kritiken, som hade bäring på såväl ståndsmotsättningarna som hattarnas borgerliga och nyadliga profil, blev ett påtagligt inslag i presidietalen från mössornas regeringsinnehav och framåt. Dess språkrör förhöll sig negativa till det tärande frälset och betonade samhällets närande lemmar, i synnerhet borgarna. Kritiken hade dock instrumentella övertoner och klara gränser - det handlade om nytta och villkorad jämlikhet, inte om egalitarism.

Trots att presidietalen under mössregimen mer än förut kom att innehålla formuleringar om ekonomisk självreglering och delvis problematiserade hattpolitiken, hushållningen och aspekter av samhället, gav huvuddelen av dem uttryck för hattvänliga ställningstaganden, låt vara för det mesta i reviderad form. Akademisekreteraren Wargentin ådagalade under den sena frihetstiden politisk försiktighet och en vacklande hållning i ekonomisk-politiska frågor, vilket liksom attackerna mot och revisionerna av hattpartiets ståndpunkter kan tolkas i ljuset av det ekonomiska krisläget, manufakturpolitikens oinfriade löften och mössornas placering vid riksrodret.

Flera ledamöter företrädde efter hattarnas återtagande av makten 1769 en välvillig inställning till handeln, under det att föreställningar om nyttofrämjande konkurrens tilltog i styrka. Konkurrensen betraktades dock regelmässigt som en funktion av de styrande snarare än som någon autonom ekonomisk kraft. Den ekonomiska självregleringen tonades inte för inte ned i presidietalen. Ordförandena tenderade i övrigt att med 
modifikationer ansluta sig till det ideologiska arvet från hattpartiets glansdagar. Det mest särpräglade talet under hattarnas andra maktinnehav kom från Schönberg, som försvarade centrala delar av deras politik men ändå stod för självreglering och icke-interventionism. Han var förutom Högström och Löwenhielm den frihetstida ledamot som mest eftertryckligt ifrågasatte akademiens vedertagna ekonomiska ideologi.

Vetenskapsakademiens presidietal speglade den övergripande ekonomisk-politiska situationen under den gustavianska eran, då protektionismen och regleringsapparaten mjukades upp, intresset för jordbruket ökade och manufakturpolitiken hamnade i skymundan. Manufakturvänligheten sjönk undan i talen, som när de gav sig in på frågan om näringarnas företräde vanligtvis favoriserade jordbruket. Fastän importfientligheten och framhållandet av förädling bestod under hela undersökningsperioden saknade utsagorna om import överlag den skarpa ton som utmärkt många av de frihetstida talen, medan substituering av importvaror genom acklimatisering av främmande växter intog en mer framskjuten plats. Ledamöterna rekommenderade som förut arbetsfördelning mellan landsorter och näringar, men hade i allmänhet en märkbart mer nyanserad hållning till mångsyssleri. Akademimedlemmarna förde också de senfrihetstida attityderna till handel och konkurrens vidare. Frihetliga uppslag vann åter mark, då ett antal gustavianska presides - inte minst Rosenstein den yngre - vände sig emot tvång och ställde sig bakom en mer eller mindre spontan ordning.

En sammanvägning av Vetenskapsakademiens politiska och ekonomiska ideologi utifrån den hittillsvarande studien av presidietalen påvisar några gemensamma drag. För det första att de förenades av en tilltro till samhällsledningens ingripanden i och reglering av den mänskliga samlevnaden. För det andra att makthavarna och eliten tillmättes en central status i samhällsgemenskapen. För det tredje att 1700-talets samhälle upplevdes som "ekonomiskt dynamiskt men socialt statiskt" - lycksaligheten skulle nås genom bättre resursutnyttjande, inte genom samhällets omstöpning. ${ }^{49}$ Nästa kapitel, som klarlägger akademiens syn på kungahuset och monarkerna, adderar till dessa slutsatser, medan den inverkan som närheten till samhällsledningen hade på organisationens idéskapande ges ytterligare belysning. 